\title{
ANÁLISIS TÁCTICO DE LAS FORTIFICACIONES IBÉRICAS*
}

\author{
POR
}

FRANCISCO GRACIA ALONSO

\section{RESUMEN - ABSTRACT}

El objetivo del presente trabajo es realizar un análisis de las características poliorcéticas de las fortificaciones ibéricas (siglos V-II a.C.) desde el punto de vista del desarrollo de la estrategia, táctica de asalto y defensa, después del desarrollo de los sistemas arquitectónicos complejos y la introducción de las máquinas de guerra en el Mediterráneo central y occidental. La documentación arqueológica se contrasta con los textos de las fuentes latinas y griegas referidas a los periodos de la Segunda Guerra Púnica y la represión catoniana (218-195 a.C.), y los relatos de las descripciones realizadas por los tratadistas griegos en el campo de la poliorcética.

The objectif ot this work ist the conceptual analysis of the poliorcetic building techniques at the iberian fortifications (V-II B.C.) after the development of the avanced strategy and tactics theories from the assault and defense of towns in the classical world. The archaeological documentation are compared with the informations supplied by the greek and latin sources refereed at the Second Punic War period, and the roman conquest of the Iberian peninsula. Another theme of analisys are the descriptions made by greek poliorcetic analysts.

\section{PALABRAS CLAVE - KEY WORDS}

Cultura Ibérica. Fortificaciones. Poliorcética. Máquinas de guerra. Artillería clásica. Estrategia militar.

Iberian Culture. Fortifications. Poliorcetic. War machines. Classical artillery. Military tactics.

\section{INTRODUCCIÓN.}

El estudio de las fortificaciones en el ámbito de la cultura Ibérica se ha orientado en los últimos años hacia la definición del concepto de fortificación y el enunciado del valor simbólico de la arquitectura poliorcética como parte principal de un lenguaje representativo territorial, económico y social (Gracia, 1997a, 1997b, 1999). Las características arquitectónicas y la complejidad de los sistemas militares que engloban han tenido como última consecuencia la negación del uso bélico de las fortificaciones, tomando como base teórica para ello la imposibilidad de que las mismas pudieran ser ni tan sólo objeto de ataque en función de los recursos técnicos y tácticos propios de las estructuras sociales ibéricas (Moret, 1996).

Como hemos indicado en anteriores trabajos, la fortificación es un elemento de cohesión social que simboliza la unión de un grupo suprafamiliar o clánico bajo parámetros políticos y no de relación de parentesco próximo/lejano, pero que aún y definiendo el espacio del oppidum que vertebra a los integrantes del grupo como miembros de una colectividad por asocia-

\footnotetext{
* Este trabajo se ha realizado dentro del proyecto PB95-1130.
} 
ción de hábitat, tiene un carácter militar, puesto que si no fuese así, la complejidad y la remodelación constante de los trazados no tendría sentido ni amortizaría la inversión de corveas y materiales necesarios para su construcción. En consecuencia, deben replantearse y analizarse las características que definen el empleo con fines militares de las fortificaciones, y el hecho de que las mismas sean esencial y prioritariamente concebidas para la defensa de los núcleos de población, como base de su análisis interpretativo.

\section{LAS FUENTES CLÁSICAS COMO BASE DEL ESTUDIO POLIORCÉTICO.}

Es un hecho asumido que los textos clásicos constituyen una de las principales fuentes de información sobre el mundo antiguo, y que, en muchos casos, la reconstrucción de los procesos históricos de un período se ha basado casi exclusivamente en su análisis e interpretación. No obstante, la aproximación al contenido de estas obras debe ser en todo momento eminentemente crítica. Los textos latinos o griegos que relatan la Historia de Roma son subjetivos y hagiográficos respecto de los triunfos de la urbs, o de los militares y políticos que la dominan o ejercen su política, a los que se convierte en sujetos de la Historia. En muchos casos, como en el de la familia de los Escipión, los protagonistas de los hechos cuentan con historiadores dependientes de su estructura política, social o económica (Polibio en este caso), que relatan los acontecimientos en los que intervienen sus miembros más destacados desde una óptica concreta. La objetividad y el relato imparcial están determinados por estas premisas, por lo que las referencias a las estructuras sociales no romanas se incluyen desde una perspectiva de superioridad, ya sea etnográfica (la descripción de comunidades bárbaras) o política (la descripción del enemigo que carece de razón en la lucha). Las informaciones serán en consecuencia fraccionarias y presentadas a través del tamíz romano.

Con respecto a la cultura Ibérica y a la Segunda Guerra Púnica en la península, las fuentes principales son los trabajos de Tito Livio y Polibio. Ab Urbe Condita (Desde la fundación de la ciudad) describe en sus libros 21 a 30 la guerra del 218-202 a.C.; en ellos, Tito Livio (59 a.C.-17 d.C.), describe unos hechos que le son relativamente próximos pero con una reducida visión crítica de aquello que relata. Aunque ha sido considerado como un texto objetivo por las simpatías republicanas del autor (pese a que fue amigo de Augusto y del futuro emperador Claudio, máximo exponente el primero del tránsito hacia el sistema de poder unipersonal en Roma) hasta el extremo de que Dante Alighieri acuñó la expresión $\mathrm{Li}$ vio che non erra (Inferno, 28, 12) para referirse a la exactitud de sus escritos, la estructura de su obra se aproxima a la poética. En el relato de los enfrentamientos militares mantiene siempre la misma cadencia retórica, siendo el esquema más común de sus descripciones de un combate, el que muestra a las fuerzas de los adversarios insistiendo siempre en la inferioridad numérica romana, para seguir con el inicio de la lucha que transcurre con momentos de crisis para el ejército romano, y terminar con la intervención personal del general que provoca una reacción de sus tropas hasta conducirlas a la victoria, concluyendo con la enumeración de las bajas de ambos contendientes, siempre elevadas entre los vencidos y muy débiles entre los romanos a pesar de lo arduo de la lucha (Gómez, 1995).

De la obra de Polibio se conservan básicamente los libros 1-5 de Historias y otros fragmentos diversos. A diferencia de Tito Livio, el escritor de Megalópolis es contemporáneo (c. 200-118 a.C.) de una parte de los hechos que narra, puesto que formó parte del séquito de Publio Cornelio Escipión Emiliano durante los asedios de Cartago y Numancia, y pudo acceder a relatos orales de las principales acciones de la Segunda Guerra Púnica. Su experiencia militar proporciona un valor añadido a la descripción de las acciones bélicas, de las que elimina la estructura poética. No obstante, su dependencia personal de los Escipión tiñe de hagiografía buena parte de la obra, alcanzando su máxima expresión en el libro 38 cuando el 
vencedor de Cartago reflexiona amargamente sobre las ruinas de la ciudad en relación con el futuro de Roma, citando los versos de Homero. Coetáneo de los hechos que relata es también Marco Porcio Catón (234-149 a.C.) aunque, obviamente, la narración de su propia campaña en la península Ibérica el año 195 a.C. dista mucho de ser objetiva (Kytzler, 1989).

Punica, la obra de Silio Itálico (26-101 d.C.), es, con sus 12.000 versos, el más largo de los poemas latinos. Basado en la estructura épica de la Eneida de Virgilio, de quien Silio Itálico era un devoto admirador, y tomando como fuente del relato la obra de Tito Livio, el poema no puede ser considerado como una obra histórica al introducir múltiples elementos ornamentales en su contenido, como la actuación de los dioses, problema al que hay que sumar la distancia cronológica con respecto a lo que describe. No obstante, en la obra de Silio Itálico se utilizan diversas informaciones sobre las tácticas de asedio y el empleo de máquinas de guerra que deben ser tenidas en cuenta puesto que corresponden a tradiciones diversas. Otros autores que aportan informaciones más fragmentadas sobre las campañas desarrolladas en la península Ibérica durante la cronología objeto de estudio, suelen trabajar a partir de obras anteriores sumando interpolaciones, como Frontino (40-104), Plutarco (46-120), Apiano (s. II d.C), Aurelio Víctor (s. IV d.C) y Zonaras. Las fuentes principales de todos ellos son las obras de Tito Livio y, en menor medida, Polibio.

Lo expuesto no significa que los textos clásicos deban ser rechazados como base de la interpretación histórica, en este caso de la poliorcética ibérica, sino que es necesaria la contrastación de las fuentes con la información arqueológica desde una óptica crítica.

Un segundo grupo de textos está formado por las obras de los tratadistas que enuncian los conceptos teóricos y la aplicación práctica de los principios poliorcéticos. Vegecio y Vitrubio definieron los siguientes principios básicos para la defensa eficaz de las ciudades (Barde,1996): noción de protección, la fortificación debe proteger a los defensores del tiro de los asaltantes; concepción de la defensa en profundidad, el acceso a las plazas debe dificultarse mediante el empleo de diversos métodos entre los que necesariamente debía incluirse la combinación de fosos y murallas; concepción activa de la defensa, la defensa pasiva o estática está condenada a ser expugnada a corto o medio plazo; flanqueo, todo el perímetro exterior de las fortificaciones tenía que situarse bajo el fuego de las torres y murallas impidiendo la existencia de ángulos muertos; y protección de las puertas, al tratarse de los puntos más débiles del sistema murario debían disponer del sistema más complejo posible de defensa.

Los conceptos indicados no fueron introducidos por Roma, sino que se basaban en las teorías expuestas y defendidas por los tratadistas griegos a partir del siglo V a.C. Junto a Eneas el Táctico (Poliorcética) y Filón de Bizancio (Poliorcética y Máquinas de Guerra), autores o compiladores de los textos más conocidos, otros escritores e ingenieros recogieron las innovaciones técnicas y teóricas en el campo de la táctica de sitio. Así, Bitón (s.III a.C.) en su obra La construcción de las máquinas de guerra y las catapultas, describe el petrobolon, ingenio para lanzar piedras obra de Caronte de Magnesia, el gastraphetes desarrollado por Zopirus de Tarento en Mileto, el elepolis, inventado por Posifonio de Mileto, y la sambuca definida por Damio de Colofonte; Ctesibios de Alejandría, autor de un tratado sobre las máquinas según Vitrubio; y Ateneo el Mecánico (siglo III-II a.C.), autor de Las máquinas de guerra, texto dedicado al cónsul Marcelo, conquistaodr de Siracusa durante la Segunda Guerra Púnica. Siendo evidente que las informaciones recogidas en estas obras son en muchos casos teóricas, su impacto en la teoría militar a partir del siglo V a.C. fue muy importante, y sus ideas (o bien otras relacionadas) pudieron perfectamente difundirse en la península Ibérica mediante los canales indicados infra. 


\title{
GUERRA Y CONOCIMIENTO POLIORCÉTICO.
}

\author{
Difícilmente es vencido aquel que bien calcula tanto sus \\ propias fuerzas como las del adversario.
}

Vegecio.

El asedio de Sagunto por el ejército de Aníbal Barca el año 219 a.C. es el más antiguo entre los acontecidos en la península Ibérica del que se ha conservado información escrita. No obstante, las características de la poliorcética descrita y el empleo que los saguntinos realizan de los sistemas de defensa mixta ante las tácticas de asedio púnicas, indican un grado de conocimiento de la teoría poliorcética que hunde lógicamente sus raíces en una fecha anterior al último cuarto del siglo III a.C., por lo que debe deducirse que el conocimiento y adaptación de los sistemas defensivos avanzados en el mundo ibérico tuvo que realizarse en una fecha anterior a la indicada, probablemente como consecuencia de una doble dinámica, interna y externa, a las estructuras sociales ibéricas. Destrucciones como las de las fortificaciones del Puig de Sant Andreu (Ullastret) (Maluquer de Motes 1970) atribuidas sin un corpus argumentativo claro a invasiones galas acaecidas alrededor del 400 a.C., o la remodelación coetánea de las fortificaciones de Emporion (Sanmartí, Nolla, 1986) son ejemplos de la existencia de razones que potencian la necesidad de mejora de los sistemas defensivos en la península Ibérica desde fines del siglo $\mathrm{V}$ a.C.

La difusión y asimilación por el mundo ibérico de la concepción de las fortificaciones complejas adaptadas a los patrones edilicios desarrollados en el Mediterráneo central y oriental a partir del siglo $\mathrm{V}$ a.C. pudo producirse siguiendo dos vías: el conocimiento y adaptación de innovaciones tecnológicas a partir del contacto con los comerciantes y colonos semitas y/o foceos, especialmente por el flujo de mercancías púnicas desde el Mediterráneo central a partir de Ibiza, Cartago o las colonias púnicas de Sicilia y Cerdeña, y por la observación del sistema defensivo de Emporion; así como por la presencia de mercenarios ibéricos en el Mediterráneo central y oriental encuadrados en los ejércitos púnico (Diodoro, 16, 73, 3), (Plutarco, Timoleón, 28,6), (Polieno, Estratagemas, I, 28) y siracusano durante el siglo V a.C., cuya valía en el combate reflejan Tucídides (Historia de la guerra del Peloponeso, 6, 90) «con la intención de reclutar muchos bárbaros, iberos y otros de los bárbaros de aquellas partes que más fama tenían de belicosos», y Diodoro $(15,70)$ «de Sicilia salieron en dirección a Corinto para auxiliar a los lacedemonios, dos mil celtas e iberos, enviados por Dionisio el Tirano, con el sueldo de cinco meses», quienes tuvieron que conocer los nuevos sistemas defensivos de las ciudades griegas de la Magna Grecia y el Egeo.

En el período correspondiente a la expedición de Nicias a Sicilia durante la Guerra del Peloponeso (415-413 a.C.), fecha a la que se refiere el texto del discípulo de Anaxágoras, los sistemas poliorcéticos complejos derivados de la introducción de la maquinaria de asedio se conocían perfectamente en el mundo griego puesto que ya habían sido empleados por los atenienses durante el asedio de Samos el año 440 a.C., especialmente el ariete cubierto, una máquina cuya invención se atribuye a Artemón de Clazomene, ingeniero al servicio de Pericles (Diodoro, XII, 28), (Plutarco, Pericles, XXVII, 3), pero tuvieron su eclosión a partir del 409 a.C. durante la segunda invasión cartaginesa de la isla de Sicilia cuando el ejército púnico obtuvo una serie de fulgurantes victorias como consecuencia del empleo de las nuevas armas. Estos avances técnicos provocaron a su vez la respuesta de los ingenieros de Dioniso de Siracusa quienes desarrollaron a partir del año 398 a.C. las primeras catapultas de ballesta (gastraphetes) y, posteriormente, de torsión. Los mercenarios ibéricos sirvieron en las campañas mencionadas por lo que obtuvieron un conocimiento directo de los avances técnicos tanto en la construcción de máquinas de asedio y fortificaciones, como de las tácticas de sitio y defensa. 
El encuadramiento de mercenarios en un ejército era una actividad temporal ligada al pago de una soldada que se realizaba por un espacio de tiempo determinado, siendo corriente en la península que las levas se mantuvieran encuadradas durante el verano, época del año en la que se llevaban a cabo las campañas militares, regresando los soldados a sus lugares de origen en invierno, tal y como describen Tito Livio (XXI, 21) «Así, pues, como se presenta una campaña lejana y es incierto cuando volveréis a ver vuestras casas y las cosas que os son queridas, si alguno de vosotros quiere visitar a los suyos, le doy permiso. Pero quiero que estéis de regreso al comenzar la primavera, para empezar, con la ayuda de los dioses, una guerra que ha de sernos de gran gloria y provecho. A todos fue grato este permiso espontáneo de visitar a sus familias, pues sentían ya la añoranza de los suyos y preveían que habían de pasar aún más largo tiempo sin verlos. El descanso del invierno entre los trabajos reanimó los ánimos, o ya exhaustos, o a punto de agotarse, para soportar de nuevo toda suerte de fatigas. Al principio de la primavera volvieron todos según la orden» y Polibio (III, XXXV, 3). Los mercenarios que regresaron a la península a principios del siglo IV a.C. pudieron difundir los nuevos sistemas de tecnología militar y bien ellos, o más probablemente técnicos púnicos o foceos al servicio de las estructuras de poder indígenas, introducirlas en la edilicia ibérica.

\section{DEFENDIENDO UNA CIUDAD.}

¿Cuál es el concepto de la defensa? Detener un golpe. ¿Cuál es, entonces, su signo característico? La espera de ese golpe.

Clausewitz.

La premisa fundamental de la defensa de un núcleo de población se basa en la complejidad del sistema defensivo que se opone a un teórico enemigo. Cuanto más potentes sean las murallas y fortificaciones tanto más difícil será que se intente el asalto de las mismas por cuanto el número de bajas sería muy elevado sin que, por otra parte, existiesen garantías de que el esfuerzo se viera coronado por el éxito. El fracaso en un asedio comporta frecuentemente un deterioro de la moral de las tropas y el descrédito del jefe militar que lo ha dirigido, hecho que en estructuras sociales en las que el poder militar está unido al político, y ambos dependen en gran medida del ascendiente sobre los miembros de una comunidad, supone un riesgo excesivo. No disponemos de textos que indiquen la existencia de trabajos de bloqueo de oppida en el mundo ibérico antes de la presencia bárquida en la península o del empleo de técnicas de sitio y maquinaria compleja anteriores a esa fecha, pero probablemente el asedio debía producirse con relativa frecuencia como indican tanto las rápidas respuestas técnicas de los saguntinos como el empleo de una serie de contramedidas fundamentales para desbloquear una plaza, entre las que se cuentan la obtención de socorros exteriores que bloqueen o acosen a su vez al asaltante, como el desbloqueo por el rey Orison de Helicen asediada por Amílcar (Diodoro 25, 10); la persecución de un enemigo en retirada agotado por el esfuerzo de tomar una ciudad como en la acción de los carpetanos contra el ejército de Aníbal (Polibio, 3, 13, 5); la preparación de los habitantes de las mismas para resistir asedios prolongados, como en el caso de la defensa de Arbocola ante Aníbal (Tito Livio, XXI, 5, 2); o la realización de salidas como en el asedio de la capital de los Lacetanos por Marco Porcio Catón (Frontino, 3, 10.1), serie de consejos tácticos ampliamente recogida en los tratados de estrategia escritos a partir del siglo V a.C. (Gille, 1985),(Gracia, 1997 a), (Gracia, 1997b).

Analizada en función de su empleo, la arquitectura militar responde siempre conceptualmente a las necesidades estratégicas que han motivado su construcción. Si el sistema de 
guerra desarrollado en la península Ibérica a partir del siglo $\mathrm{V}$ a.C. correspondiese tan sólo al tipo de lucha heroico que se interpreta a partir del estudio iconográfico de los conjuntos escultóricos del sudeste y sur peninsulares, o en la razzia rápida y puntual que se deriva de las descripciones realizadas por algunos autores clásicos (Tito Livio, XXVIII, 32, 9) (vide sobre extremo las reflexiones de P. Moret, Moret, 1996), la existencia de sistemas de fortificación complejos sería innecesaria, por cuanto en el primer caso la victoria de un héroe en combate singular supondría la asunción de un derecho de conquista sobre el vencido y, en el segundo, el concepto del asedio es incompatible con el de rapiña derivada de una destrucción rápida. Por tanto, y con independencia de las razones que justifican la arquitectura de prestigio tratadas en anteriores trabajos, la fortificación compleja tiene que responder a la existencia de contingentes de tropas permanentes o fácilmente reclutables que puedan llevar a cabo acciones militares a gran escala entre las que se incluyan los asedios, un tipo de práctica militar diametralmente opuesta al combate heroico.

En contra de las tesis que indican que las torres de los sistemas defensivos ibéricos tenían tan sólo una función de vigía para prevenir ataques por sorpresa o razzias, consideradas como la única forma en que un ejército ibero podría expugnar una ciudad dados sus limitados recursos militares (Moret, 1996), el estudio arquitectónico de las fortificaciones indica lo contrario. La potencia de las defensas debe relacionarse con la existencia de ejércitos numerosos frente a los que fuese necesario presentar un sistema complejo de protección en el acceso a los núcleos habitados, puesto que la referencias a la toma por asalto de ciudades por parte de iberos y celtíberos son corrientes: «los celtíberos, que habían sido los primeros de esta región en enviar legados y rehenes a los romanos, excitados por un mensajero de Escipión, toman las armas e invaden la provincia de los cartagineses con un fuerte ejército. Toman por asalto tres ciudades y entablan con insigne valor dos combates con Asdrúbal, al que matan quince mil hombres y le cogen cuatro mil, con muchas enseñas» (Tito Livio, XXII, 21); «éstos tránsfugas provocaron un levantamiento entre los Tartesios, arrastrando con ellos algunas ciudades y tomando una por asalto» (Tito Livio, XXIII, 26); «se dirigen a asaltar Ascua, donde Asdrúbal, al entrar en aquel país, había dejado el grano y demás provisiones, y se apoderan del campo alrededor» (Tito Livio, XXIII, 27).

El volumen de hombres que un jefe político o militar ibérico podía reclutar depasa los conceptos numéricos que representan la banda o la elite militar. De este modo, Indortas, jefe ibero que combate contra Amílcar, consigue reunir por dos veces un ejército de 50.000 hombres (Diodoro, 25,10); Aníbal consigue dispersar a más de 10.000 enemigos en su lucha contra los vacceos según Polibio (3, 13, 5), o 100.000 según Tito Livio (XXI, 5, 2); y las tropas enviadas por Aníbal al norte de Africa antes de iniciar su marcha contra Roma son asimismo considerables: «Envió a Africa trece mil ochocientos cincuenta infantes de escudo ligero, con ochocientos setenta honderos baleares y mil doscientos jinetes de varias naciones» (Tito Livio, XXI, 21), (Polibio, 3, 33, 7), cantidades lo suficientemente importantes como para pensar en el desarrollo de tácticas de asedio y sistemas de sitio en la cultura Ibérica antes de las convulsiones bárquidas. Con independencia (y aún en oposición) del argumento esgrimido, las cifras de hombres encuadrados por los jefes políticos o militares ibéricos en sus ejércitos citadas por las fuentes clásicas han de ser necesariamente exageradas, al igual que el número de bajas sufridas. La constratación entre los datos demográficos del mundo ibérico, resultado de la aplicación de diversos modelos teóricos, y las cifras señaladas indican una gran desproporción entre la posibilidad teórica y la realidad descrita. Las bajas acumuladas en más de veinte años de campañas, que siempre sobrepasan el 50\% de los efectivos encuadrados en los combates (llegando en ocasiones hasta la práctica aniquilación) hacen imposible la subsistencia física de las tribus. La facilidad con que un ejército vencido se reorganiza permite suponer que habría más dispersos que muertos o cautivos, según un parámetro similar a los partes de victoria napoleónicos en España durante la guerra de 1808-1813. 
El acceso a las puertas se encontraba protegido por torres avanzadas y sistemas de proteichisma y epikampion que dificultaban el acceso a las mismas. Las torres se proyectan hacia delante de la línea de muralla avanzando sobre el flanco más expuesto de las puertas y poternas, forzando al asaltante a realizar un recorrido concreto para alcanzarlas, siempre de manera forzada y siguiendo el planteamiento táctico de la estrategia de defensa y no de la de ataque. Los sistemas defensivos de los poblados de Les Toixoneres/Alorda Park (Calafell) y Puig de Sant Andreu (Ullastret) son ejemplos sobresalientes de ello.

Al situar los accesos a la derecha de las torres avanzadas se crea una zona de terreno batida en la que el asaltante recibe los proyectiles de frente y de flanco, siempre por su costado derecho, aunque en ocasiones puede además encontrarse enfilado también por torres y lienzos de muro situados a su izquierda; este hecho es fundamental por cuanto la iconografía ibérica (p.e. guerreros de Cerrillo Blanco (Negueruela, 1990); guerreros de los conjuntos A y B de Osuna (Almagro Gorbea, 1983); guerrero de Mogente (Quesada, 1997); guerreros del Collado de los Jardines (Prados, 1992); o guerrero de La Alcudia (Bendala, Blánquez, 1997) por citar tan sólo algunos de los más conocidos) muestra claramente como el escudo de los caetratum se sostiene con la mano izquierda, dejando la diestra libre para el uso de las armas ofensivas. Si el guerrero es constreñido a cambiar su armamento de mano para protegerse de los proyectiles que se lanzan sobre él y no puede emplear con la zurda sus armas al no estar preparado o acostumbrado a ello, su capacidad ofensiva se anula y el defensor tendrá siempre ventaja sobre el asaltante que se verá imposibilitado para responder de forma conveniente. La forma cómo portaban las armas los guerreros iberos es descrita por Tito Livio durante el asedio de Orongis: «abriendo, pues, repentinamente la puerta, se echaron en masa fuera de la ciudad poniendo los escudos por delante por si les disparaban venablos desde lejos y mostrando desnudas las diestras para que se viera bien que habían arrojado las espadas» (XXVIII, 3).

Inicialmente, los puntos débiles de los trazados defensivos son las puertas y las poternas, por lo que se convierten en los lugares en los que se concentra la capacidad defensiva. La regla básica de la función poliorcética es mantener alejados de los muros a los asaltantes para lo que debe contarse tanto con las obras avanzadas como con la capacidad de fuego. Por ello, la estrechez del espacio dejado por los muros que constituyen los epikampion existentes ante las puertas (como en el caso de los accesos a las puertas 1 y 3 del poblado del Puig de Sant Andreu, Ullastret) tiene por objetivo convertir al mismo en una ratonera que restrinja la movilidad de los asaltantes y permita la concentración del tiro por parte de los defensores con una mínima respuesta de los primeros que, en función de lo estrecho del paso, no pueden hacer valer su número.

El desarrollo de un asedio supone la contraposición de dos estrategias. Si bien el asaltante cuenta con la ventaja de poder escoger el lugar o lugares por los que intentará penetrar en el poblado en función de sus fuerzas y/o de la posibilidad de sorprender al enemigo, siendo el caso de la toma de Cartago Nova por Publio Cornelio Escipión un excelente ejemplo de este hecho, tal y como relata Polibio $(10,12,1)$, por lo que actúa siempre en función de sus recursos y la topografía del terreno, como muestra la elección que Aníbal realiza de los puntos para atacar Sagunto: "con su temible ejército, devastó a su paso los campos y atacó por tres puntos la ciudad. Había un ángulo de la muralla que avanzaba hacia un terreno más llano y abierto que todo el territorio alrededor. Contra él mandó instalar los manteletes para poder por ellos aproximar los arietes a la ciudad» (Tito Livio, XXI, 7), el defensor cuenta con los mismos factores y, conociendo las particularidades de la aglomeración que debe defender, puede (y debe) anticiparse a los movimientos de su oponente y deducir cuáles son los puntos débiles del perímetro de la ciudad para concentrar en ellos su esfuerzo bélico. El defensor tiene que intentar dificultar al máximo la progresión de su oponente, conservando el mayor tiempo posible el control estratégico sobre el terreno inmediato a las murallas 
que puede batir con su fuego de barrera, aumentando las bajas del asaltante y retrasando (o impidiendo) que éste alcance la base de los muros o las puertas y pueda emplear torres, arietes, zapas o escalas para penetrar en el interior del recinto. En el momento en que las fortificaciones de la ciudad cedan, el número provocará que el triunfo se decante siempre del lado del asaltante, problema sobre el que advierte Eneas el Táctico: «es preferible bloquear los espacios abiertos de la ciudad que no tengan utilidad, para evitar que sean necesario destinar tropas a ellos, cavando fosos y dejándolos tan inaccesibles como resulte posible para quienes quieran provocar un levantamiento y ocupar con antelación dichas posiciones» (Poliorcética, II, 1).

Uno de los problemas básicos con los que se enfrenta el estratega que dirija la defensa de una ciudad es el número de hombres disponible. Por regla general un sitio se produce después de que el ejército de campaña de la ciudad asediada haya sido vencido, por lo que sus efectivos se habrán visto mermados por las pérdidas sufridas, hecho que condiciona la ubicación de los defensores en las fortificaciones, concentrándolos en los puntos más vulnerables, como indica Eneas el Táctico, quien sostiene que los enclaves más amenazados deben ser defendidos por los ciudadanos de mayor prestigio (Poliorcética, XXII, 15, XXVI, 10). Tito Livio, indica que durante el asedio de Sagunto los defensores carecían de efectivos suficientes para guarnecer el perímetro, lo que dificultaba su defensa: «el ejército cartaginés era muy numeroso, calculándose sus efectivos hasta ciento cincuenta mil hombres; los sitiados no bastando para defenderlo y vigilarlo todo, se vieron obligados a dispersarse» (XXI, 8). La falta de soldados será especialmente grave cuando no puedan formarse reservas para acudir a los puntos más amenazados durante los asaltos, por lo que será corriente que participen en la defensa todos los habitantes de la ciudad, como en el caso de Iliturgi: «consiguientemente, no intervienen sólo los hombres en edad militar, ni sólo los varones sino las mujeres y los niños, más allá del límite de sus fuerzas físicas y morales, les alcanzan armas a los combatientes, les llevan piedras a los que refuerzan los muros» (Tito Livio, XXVIII, 19) o en la toma de Salmantis por Aníbal en la que algunas mujeres combaten junto a los hombres: «los bárbaros le suplican que les permita salir con sus mujeres y con la ropa de diario y dejar armas, bienes y esclavos. Las mujeres, tras ocultar espadas en su regazo, salieron con los hombres. Los soldados de Aníbal, efectivamente, saqueaban la ciudad, y las mujeres, alentando con sus gritos a los hombres, les dieron las espadas; y algunas incluso, sacándolas ellas mismas, atacaron con los hombres a los que saqueaban la ciudad, de suerte que derribaron a unos y rechazaron a otros y en tropel se abrían camino a golpes. Aníbal, admirado del valor de las mujeres, devolvió por ellas a los hombres la patria y los bienes» (Polieno, Estratagemas, VII, 48), (Plutarco De Virt.Mul. X, 248).

\section{FUEGO DE COBERTURA.}

Nunca la sombra vil vieron del miedo, y aunque soberbios son, son reputados, todo lo resuelven en cualquier asalto, sólo no sufren que les hablen alto.

\section{Pedro Calderón de la Barca.}

La libertad de movimientos bajo el fuego realizado desde las murallas era muy restringida. Silio Itálico indica que los zapadores púnicos se aproximaron a la base de los muros de Sagunto formando una tortuga (testudo) con sus escudos, acción que sólo puede realizarse bajo la protección de un fuego de cobertura nutrido, puesto que el propio del grupo es nulo: "por último, juntando sus escudos, los cartagineses forman una tortuga de filas cerradas; es un muro que avanza, un reducto al abrigo del cual zapan en secreto la muralla» (Punica, 
I,365), del mismo modo que los romanos asaltarán la muralla de Cartago Nova por la marisma: «se inflamó tanto su espíritu, que hecha la tortuga arremeten la puerta y prueban desde fuera de hacerla pedazos con hachas y azuelas» (Polibio, 10,12,1). El fuego de cobertura del asaltante tiene como objetivo limpiar de defensores las murallas para permitir el trabajo de los zapadores y los arietes como en el asedio de Cástulo por Publio Cornelio Escipión el año 206 a.C.: «entonces se abatió el ánimo de los habitantes, y desalojados los defensores fueron ocupados los muros, en la confusión del asalto, la ciudadela hasta por aquella parte que parecía inexpugnable fue tomada» (Tito Livio, XXVIII,19), o en el de Masalia el año 48 a.C.: «el músculo es defendido desde la torre de tabiques por los nuestros, mediante dardos y proyectiles de artillería; los enemigos se ven obligados a retirarse de sus murallas y de sus torres, no se les da oportunidad de defender libremente su baluarte» (Bello Civile, II,XI,3), siendo interesante un texto de Claudio Cuadrigario (Frag.Hist,85) en el que indica la pericia de las tropas del procónsul de la Hispania Ulterior, Claudio Cecilio Metelo, el año 78 a.C. en esta táctica: «saeteros y honderos disparan con gran ahínco por ambas partes. Pero no es lo mismo lanzar una piedra o saeta hacia arriba que hacia abajo; pues es difícil lanzarlas con certeza hacia abajo, mientras que hacia arriba se lanzan las dos muy bien, por lo cual los soldados de Metelo recibían muchas menos heridas, y, lo que más importaba, los honderos con toda facilidad desalojaban de las almenas a los enemigos».

Durante el asedio de Sagunto, y según el relato de Silio Itálico, el propio Aníbal Barca participa en el fuego de cobertura que realizan sus tropas para permitir la aproximación a las murallas: «en primera fila, vestido con las armas de su padre, Aníbal está en todas partes: lanza proyectiles de fuego, se bate infatigable con un venablo y una lanza, con piedras, toma su arco y lanza flechas impregnadas de veneno doblemente mortíferas y se alegra de tener en su carcaj este arma traidora» (Silio Itálico, Punica, I, 320-325).

\section{FUEGO DE BARRERA}

Frente al enemigo, todas las ventajas son buenas, y por mi parte, si pudiese conjurar a todos los demonios del infierno para machacar los sesos de mi enemigo, antes de que machacara los míos, lo haría de todo corazón.

Blaise de Montluc.

El concepto del fuego defensivo o de barrera parte de la potencia o alcance medio de las armas de mano que se suponga vayan a ser empleadas de forma común por los defensores, estimándose preferible realizar los cálculos básicos de la defensa sobre el volumen de fuego que pueden sumar las acciones individuales de los soldados, que sobre la calidad y precisión del fuego obtenido mediante el empleo de máquinas, puesto que la recarga de las mismas era muy lenta y, en consecuencia, su empleo muy deficiente e inadecuado para contrarrestar el mayor peligro con el que se enfrentaban los defensores de una plaza: impedir que el asaltante recorriera con cierta comodidad la distancia existente entre sus posiciones de partida (situadas fuera del alcance del tiro de los defensores de la ciudad), y la base de los muros, en la que plantaban las escalas o intentaban derribar con ayuda de arietes, eligiendo por regla general ángulos muertos situados fuera del alcance del tiro defensivo. Tito Livio indica que la potencia del fuego de barrera de los defensores de la ciudad de Orongis el año 207 a.C. era de tal magnitud que impedía la aproximación de los soldados de Lucio Escipión: «cuando el primer cuerpo inició el ataque hubo una lucha terrible pero de resultado incierto: no resultaba fácil acercarse a los muros ni aplicar escalas debido a los proyectiles que caían» (XXVIII, 3). 
Filón de Bizancio, en sus obras Poliorcética y Máquinas de guerra, indica que los tramos de muralla entre torres u obras avanzadas no debían sobrepasar el alcance del tiro efectivo de las armas de mano, cifrando esta medida en un máximo de 100 codos $(46,2 \mathrm{~m})$ que corresponde, por ejemplo, a la mitad del tiro de precisión con honda, cifrado por John Warry (Warry, 1980) en $100 \mathrm{~m}$ para los experimentados honderos cretenses citados por Jenofonte (Anábasis, III, 3). El concepto modular en la construcción de los sistemas defensivos adaptado a cánones concretos de balística se refleja, por ejemplo, en la longitud de los tramos de la Muralla Frigoleta del Puig de Sant Andreu (Ullastret), que miden respectivamente 29,45 m en el sector F-G; 29,58 en el H-I, 28,56 en el J-L y 27,05 en el M-O, tramos enmarcados siempre entre dos torres avanzadas de medidas asimismo regulares (Gracia 1997a), que responden a una modulación de origen griego observada también en otros asentamientos de la costa del levante peninsular como es el caso de La Pícola (Moret, 1998). La aplicación de las tesis de W.Marsden (Marsden, 1969) al trazado de ésta y otras fortificaciones ibéricas erigidas siguiendo sistemas poliorcéticos complejos, indica que el terreno existente ante las murallas se encuentra siempre batido desde múltiples puntos, organizándose de esta forma una defensa con fuego de apoyo por tramos que incluye, como mínimo, el procedente de dos torres y un tramo de muralla para un mismo sector; si en la construcción de los lienzos de muralla se incluían además segmentos concatenados, aplicando el sistema del trazado en cremallera como propugnaba Filón de Bizancio, la propia cortina muraria disponía de zonas avanzadas para proteger con tiro lateral secciones de la misma.

Del mismo modo, Polibio relata que Publio Cornelio Escipión, durante el combate del istmo de Cartago Nova, se hacía acompañar por dos soldados que le protegían de los proyectiles que lanzaban desde las murallas, siendo este dato especialmente significativo por cuanto el cónsul romano se encuentra tras las líneas de su ejército que combate ante los muros de la ciudad con parte de la guarnición púnica, por lo que se deduce que todo el campo de batalla se encontraba bajo el fuego de cobertura de los defensores apostados sobre los muros, que alcanzaba una distancia superior a dos estadios (c.354 m), distancia que sólo podía ser cubierta con máquinas, ya que el alcance máximo del arco o de la honda son inferiores, incluso en el tiro por salvas de poca precisión: «llevaba consigo tres soldados armados, los cuales cubriéndole y defendiéndole con sus escudos de los tiros que venían del muro, procuraban su seguridad» $(10,12,1)$. El texto hagiográfico de Polibio debe no obstante exagerar la importancia del fuego de cobertura realizado desde los muros de Cartago Nova, por cuanto la distancia de casi $400 \mathrm{~m}$ que separaría a Publio Cornelio Escipión de las fortificaciones tan sólo podría cubrirse de forma efectiva con proyectiles lanzados por máquinas $\mathrm{y}$, en este caso, difícilmente un escudo podría ser una protección eficaz puesto que la fuerza del impacto de los mismos no tan sólo derribaba filas enteras de soldados (tal y como indica Cayo Julio César en su relato del sitio de Avaricum el año 52 a.C., Bello Gallico, VII,26) sino que podía partir a un hombre por la mitad, proyectando su cabeza a más de tres estadios (c.530 m) de distancia (como indica Flavio Josefo en el sitio de Jotapata de Galilea el año 63 d. C., Bello Judaeo, III,243-247), atravesando cascos y corazas, como en el caso de la herida que recibió Alejandro Magno durante el asedio de Gaza el año 332 a.C.

La importancia de este fuego puede cuantificarse por el hecho de que en el recuento de material tomado al conquistar la ciudad figuran 120 catapultas grandes, 280 catapultas pequeñas, 23 balistas grandes, 52 balistas pequeñas, así como escorpiones, dardos y diversos tipos de armas arrojadizas (Tito Livio, XXVI, 47, 5), lo que supondría un arma pesada cada siete metros si tenemos en consideración que Polibio $(10,10,1)$ indica que el perímetro de la muralla era de veinte estadios (c.3540 m), no siendo probable que todas ellas entrasen en acción durante el combate puesto que el gobernador de la ciudad, Magón, disponía tan sólo de cuatro mil hombres (dos mil pertenecientes a la guarnición y otros dos mil reclutados de emergencia entre los habitantes de la ciudad) de los que más de la mitad combaten fuera de 
la ciudad; sobre esta cifra, el propio Tito Livio admite la existencia de diversas tradiciones, por cuanto el historiador griego Sileno indicó que tan sólo se tomaron sesenta escorpiones entre grandes y pequeños, mientras que Valerio Anciate elevó el número de máquinas a seis mil escorpiones grandes y trece mil pequeños, lo que, según Tito Livio, indica que hay poco reparo en mentir (Tito Livio, XXVI,49). Siendo necesario un mínimo de cuatro servidores para accionar las máquinas de este tipo con una cadencia de disparo óptima, es evidente que el parque de artillería descrito correspondería más a la reserva del ejército de campaña cartaginés que al armamento de defensa de la ciudad.

El término fuego defensivo engloba de hecho todos los tipos de materiales arrojadizos que puedan lanzarse sobre los atacantes, procedentes tanto de armas de mano como materiales de derribo o fortuna acumulados en los pasos de ronda y las torres.

La aplicación de los principios poliorcéticos de origen mediterráneo en la construcción de fortificaciones como las ya citadas del Puig de San Andreu (Ullastret) (Gracia, 1997a), o las del Castellet de Banyoles (Tivissa) (Pallarés, 1983-1984) (Gracia, Munilla, Pallarés, 1991), Turó del Montgròs (El Brull) (Molist,Rovira, 1991) Les Toixoneres-Alorda Park (Calafell) (Sanmatí,Santacana, 1991a, 1991b, 1994), La Serreta (Alcoy) (Llobregat, 1995) o incluso Cerro de Capote (Higuera la Real) (Berrocal, 1994), se realiza en base al conocimiento de las máquinas de guerra. No obstante, no se ha documentado arqueológicamente ninguna máquina de este tipo en asentamientos ibéricos, correspondiendo los dos ejemplos más antiguos conocidos en la península Ibérica, las euthytonon de Emporion y Caminreal, al período romano republicano, aunque este tipo de catapulta de torsión se desarrolla a partir de mediados del siglo IV a.C.

Sin embargo, este hecho no debe servir para negar la existencia de máquinas en las fortificaciones ibéricas. Silio Itálico (Punica, I, 334-335) indica que los defensores de Sagunto emplean balistas foceas en referencia a las máquinas opuestas a los cesarianos por los defensores de Masalia (Bello Civile, 1, 34, 5): «la balista focea lanza bloques de piedra, se la recarga con un nuevo proyectil, enorme, un vástago armado con hierro que golpea las filas enemigas y las aplasta», y aunque la cita puede ser apócrifa, la distancia a la que llegan los proyectiles lanzados por los defensores de Atanagro en el 218 a.C. durante el asedio que realiza Cneo Cornelio Escipión a la ciudad indicaría asimismo el empleo de máquinas por los defensores de la ciudad (Tito Livio, XXI, 61), y Publio Cornelio Escipión afirma que en Cartago Nova se guardaba el parque de artillería del ejército púnico: «aquí están las catapultas, las armas y todo el material bélico, que os equipará a vosotros y al mismo tiempo dejará sin nada al enemigo» (Tito Livio, XXVI, 43).

La referencia que Silio Itálico realiza de una balista focea permitiría indicar en primera lectura la existencia de fuertes relaciones entre las colonias foceas de Masalia y Emporion con Sagunto, hecho que ha demostrado ampliamente la documentación arqueológica (especialmente las cartas comerciales que relacionan a emporos de las tres poleis) (Gracia, 1996), dentro de las que se incluirían la difusión de los conceptos de la ciencia poliorcética como copia o adaptación de los sistemas defensivos ampuritano y masaliota. No obstante, la referencia puede hacer mención a la impresión que causó en el mundo antiguo la defensa por espacio de ocho meses de una pequeña ciudad frente al ejército cartaginés, comparando Silio Itálico la destreza de los medios utilizados durante el sitio por los saguntinos con los empleados por los masaliotas durante el asedio que el legado Cayo Trebonio puso a su ciudad por orden de Cayo Julio César el año 48 a.C., puesto que en el relato que el propio César realiza de esta operación se expresa admiración por el empleo que los asediados hacían tanto de máquinas de guerra como de diversos sistemas de oponerse al empleo de ingenios de sitio por parte de los cesarianos: «pero tal era, desde hacía mucho tiempo, la reserva de máquinas guerreras que había en la ciudad y tanta la cantidad de artefactos de artillería, que no podía contrarrestar su poderío ningún mantelete revestido de zarzos. Porque vigas de doce pies, 
provistas de aguijones, disparadas por enormes catapultas, aún después de atravesar cuatro setos de zarzos, quedaban clavadas en tierra» (Bello Civile, II, II, 1-2).

La ubicación de las máquinas de guerra en las fortificaciones se concentraba en las torres, que debían disponer de plataformas a diferentes alturas dotadas de troneras para facilitar el disparo puesto que las balistas realizaban un tiro tenso y no parabólico. La ubicación en altura de las máquinas permitía ampliar el alcance de las armas, puesto que la distancia obtenida (L) al disparar desde una altura concreta (h) se veía incrementada en la proporción 2 L al duplicar h. Algunas torres de los poblados anteriormente citados responden perfectamente a las descripciones clásicas sobre la construcción de casamatas de tiro, como es el caso de la torre del istmo de la muralla del Puig de Sant Andreu (Ullastret), o las torres de Turó del Montgrós (El Brull) y Alorda Park-Les Toixoneres (Calafell), estas últimas relacionables con las fortificaciones púnicas de Mothia (Sicilia).

Junto a los proyectiles de piedra, en las máquinas se empleaban también los de ánima metálica pensados como soporte de materias inflamables. El fuego ya se empleaba contra las máquinas de guerra en el mundo asirio, puesto que en los relieves del palacio de Senaquerib en los que se relata el asedio de la ciudad de Lachish, se muestran soldados ubicados en el interior de los arietes cubiertos lanzando agua sobre la carcasa para impedir que el fuego prenda en ella. Eneas el Táctico (XXXIII, 1-2) indica que las mezclas de pez, estopa y azufre son el mejor combustible para oponerse a las máquinas (el fuego griego empleado en los asedios de Platea y Delión el año 424 a.C. en el transcurso de la Guerra del Peloponeso, según Tucídides II,77; IV, 100), debiéndose utilizar del modo siguiente: «preparad palos parecidos a los mazos de mortero, pero de un tamaño mayor; en los extremos del palo clavad puntas de hierro, unas grandes, otras más pequeñas, y en el resto del palo, arriba y abajo, atad, por separado, preparados de alto poder incendiario. Su apariencia debe ser similar a la de un rayo como los que son representados en las pinturas. Este preparado debe ser lanzado contra la máquina que se esté aproximando, dispuesto de manera que quede fijado sobre la máquina y que el fuego, como está clavado, se mantenga». Este sistema es similar al empleado por los saguntinos, llamado falárica, un arma de tipo individual descrita por Tito Livio (XXI, 8): «usaban los saguntinos una arma arrojadiza llamada falárica, cuya asta era de abeto y redonda en toda su extensión excepto en el extremo donde se colocaba el hierro; éste, cuadrado como en el pilum, estaba rodeado de estopa empapada de pez. El hierro era de tres pies de largo para poder traspasar la armadura y el cuerpo. Pero aún en el caso de quedar clavado en el escudo y no penetrar en el cuerpo, llenaba de terror, pues como se lanzaba encendido y su carrera avivaba la llama, obligaba al soldado a despojarse de sus armas y exponerse indefenso a los golpes siguientes», aunque la descripción que Silio Itálico realiza del mismo artefacto (Punica, I, 350-364) se refiere a un proyectil lanzado mediante máquinas: «la falárica, que para lanzarse precisa de muchos brazos. Es una terrible pieza de madera de abeto obtenida en las cumbres nevadas de los Pirineos erizada de puntas de hierro, ingenio destructor presente siempre en las murallas, cuyo fuste esta recubierto de pez espesa y azufre negro que se inflama. Como un rayo es lanzada desde las murallas hendiendo el aire que se abre ante su llamarada, similar al meteoro de fuego que cae del cielo sobre la tierra (...) cuando se hunde en el costado de una enorme torre, el fuego de Vulcano muerde profundamente las mamparas de madera hasta que termina por quemarse aplastando armas y hombres bajo los escombros ardientes». En una época muy posterior, el año 1107, el fuego fue también el arma empleada para acabar con la torre móvil con que Bohemundo intenta ocupar la ciudad de Durrës (Albania), según refleja el texto Alexia de Anna Commeno (1083-1148) en el que relata el reinado de su padre Alejo I (1069-1118) (Bradbury, 1992).

Los proyectiles de fuego tenían una doble motivación: quemar las máquinas y obras de asedio que los asaltantes intentaban aproximar a la muralla, y causar el terror entre los soldados por el tipo de heridas que causaban las mezclas de materias inflamables utilizadas, hasta 
tal punto que incluso el propio Eneas el Táctico indica las precauciones que deben tomarse para luchar contra los incendios provocados durante un asedio: «quienes apaguen el incendio desde posiciones elevadas, deben tener una protección en el rostro, con el objeto de que sufran un daño menor cuando el calor de las llamas les afecte» (Poliorcética, XXXIV, 2). El hecho de que el empleo de proyectiles de fuego era un recurso frecuente de los asediados contra las máquinas se plasma en la descripción que Tito Livio realiza del asedio que Cneo Cornelio Escipión realiza de Atanagro, capital de los ilergetas el primer año de su presencia en la península: "Treinta días duró el asedio, durante los cuales raras veces el espesor de la nieve fue inferior a cuatro pies; de tal modo había cubierto las máquinas y manteletes de los romanos, que ella sola bastó algunas veces para defenderlas del fuego que el enemigo les echaba» (XXI, 61).

Con todo, la mayor parte de los proyectiles lanzados desde las torres y murallas lo eran por armas de mano, destacando entre ellas la honda y el arco. Las armas arrojadizas propias de la panoplia ibérica, como la lanza o el soliferreum, no pueden emplearse con comodidad desde una posición elevada para efectuar un fuego de cobertura, puesto que la anchura de los pasos de ronda y las dimensiones de las plataformas de las torres impiden que el soldado tome impulso a la carrera para proyectar su arma, con lo que la distancia que puede cubrir el proyectil es muy reducida. Este tipo de armas de asta podría emplearse en un tiro cenital cuando el enemigo hubiera alcanzado la base de los muros o para impedir que se coronasen los mismos mediante escalas, aunque en ambos casos, el arma se perdería rápidamente restando al soldado tan sólo sus armas de puño. A este elemento debe añadirse el factor de riesgo que supone el tiro cenital al tener que pasar el defensor el cuerpo por encima del parapeto, con lo que quedaría muy expuesto al fuego de cobertura del atacante.

El empleo de la honda por parte de los iberos está ampliamente documentado en las fuentes clásicas, especialmente en los textos referidos a los honderos baleáricos (Tito Livio, XXI,55,6), (Silio Itálico, Punica, III,364-365). Los proyectiles de honda podían ser de piedra o plomo, siendo éstos últimos, corrientes en el mundo griego, con un peso de entre 30 y 35 gr. pudiendo alcanzar el disparo del proyectil hasta una distancia de $200 \mathrm{~m}$. con un elevado índice de acierto. Pese a que en algunos yacimientos como Puig de Sant Andreu (Ullastret) (Oliva,1960), (Gracia,1996-1999), y Pech Maho (Moret,1996) se han documentado depósitos de cantos rodados en las torres o en los edificios anexos a las mismas que pueden interpretarse como pequeños arsenales o reservas de proyectiles, el empleo de hondas sobre los muros o parapetos presenta serias dificultades. Si el hondero realiza el giro del brazo paralelo al cuerpo, la salida del proyectil que tiene lugar por la parte inferior del círculo descrito puede topar con las almenas o balaustradas de murallas y torres, puesto que el tiro parabólico con honda se realiza de abajo hacia arriba. Si por el contrario, el hondero hace girar su arma por encima de su cabeza describiendo un círculo transversal al cuerpo, como en el pasaje bíblico del encuentro de David y Goliat (1 Samuel, 17), el problema surge por el número de personas que puede realizar éste movimiento a un tiempo, ya que el espacio necesario para un giro como el descrito disminuye la densidad de defensores en los parapetos y, en consecuencia, el volumen de fuego de barrera que se realiza, cuyo fin es convertirse en una lluvia de piedras como la que se abate sobre Aníbal en Sagunto: «será entonces cuando, blandiendo sus hondas, harán llover sobre él balas de plomo» (Silio Itálico, Púnica, I, 523-524).

El empleo de las honda para realizar fuego de barrera contra los asaltantes o de cobertura para proteger a los zapadores se conoce desde finales del segundo milenio, estando representado en los relieves del palacio de Senaquerib (704-681 a.C.) en Assur en los que se representa el asedio y toma de la ciudad de Lachish. Integrados en las tropas permanentes (kisir sharruti) de infantería (zuku) del ejército asirio los honderos y los arqueros (nash qasti) formaban unidades específicas, y fueron ampliamente utilizados a largo de las campañas del imperio neoasirio (745-609 a. C.), especialmente durante los reinados de Tiglat-Pileser III 
(745-727 a.C.), Sargón II (721-705 a.C.) y el propio Senaquerib. Los textos de los archivos reales indican que los proyectiles empleados por los honderos asirios eran piedras irregulares de $6 \mathrm{~cm}$. de diámetro máximo y un peso comprendido entre 193 y 270 gr., aunque en Grecia y en la península Ibérica el peso de los glandes de plomo era mucho menor, estando comprendidos entre los 30 y 80 gr. con un peso medio estimado de 59 gr., según algunas fuentes, aunque otras, como Diodoro, indican que el peso de los proyectiles utilizados por los honderos baleáricos sería de una mina (436 gr.) (Head, 1982).

Los honderos tenían que colocarse muy próximos a las murallas para realizar su tarea por cuanto el alcance máximo de las hondas se estima en $300 \mathrm{~m}$ pero con una eficacia muy reducida siendo aconsejable lanzar a menos de $200 \mathrm{~m}$ y, a ser posible, entre 50 y 75 para obtener un elevado grado de precisión. En todos los casos, los soldados que realizasen un fuego de cobertura debían situarse dentro del radio de acción operativo del fuego de barrera efectuado desde torres y murallas.

Los honderos y arqueros asirios hostigaban a los defensores de las murallas parapetados tras soldados que les protegían con sus escudos, como se muestra en los relieves del palacio de Asurbanipal (Healy,1995b) ya que por el tipo de arma que empleaban les era imposible portar un escudo al mismo tiempo, constituyendo un tipo de asociación defensiva que posteriormente sirvió de base al dathabam persa, en la que la primera línea de soldados (sparabara) provistos de escudos (spara) se situaba al frente de la formación para permitir el tiro de los arqueros. El guerrero escolta de los arqueros se emplea también en el mundo griego, donde los arcos y arqueros escitas se representan desde mediados del siglo VII a.C., siendo frecuente su asociaciación con hoplitas que los protegen con sus escudos en la cerámica ática del siglo VI a.C. (Snodgrass, 1967). Esta táctica se practicó ampliamente en Europa durante la Guerra de los Cien Años, en la que los ballesteros franceses se colocaban en la línea de batalla protegidos por los pavisiers, hombres de armas provistos de escudos. Es significativo el hecho de que la cronología de los relieves del palacio de Senaquerib coincida con la de la compilación definitiva de la Ilíada, atribuida a Homero, durante la segunda mitad del siglo VIII a.C., en la que se relata (IV, 90-125) como Pándaro, rey de los licios, consigue herir a Menelao con una flecha lanzada bajo la protección de los escudos de sus hombres, acción que repite Teucro, quien se parapeta entre los disparos tras el escudo de Ayax el Telamonio (Ilíada, VIII, 265-270).

La eficacia de los honderos en el Próximo Oriente se refleja en la obra de Jenofonte (Anábasis,III,3) al indicar el valor de los honderos persas durante la persecución de los auxiliares griegos de Ciro el Joven en retirada el año 400 a.C. tras la batalla de Cunaxa: «apareció ante sus ojos Mitrídates con unos doscientos jinetes y unos cuatrocientos arqueros y honderos, terribles por su agilidad y por ser muy buenos corredores (...) sus jinetes e infantes comenzaron a lanzar flechas sin previo aviso y los honderos, por su parte, arrojaron piedras que causaron muchos heridos», debiéndose recurrir, a propuesta de Jenofonte, a la formación de unidades de honderos rodios, célebres por su reputación con este tipo de arma: «necesitaremos lo antes posible, honderos y jinetes. Me parece que en nuestro ejército hay rodios, muchos de los cuales, según dicen, saben manejar la honda, lanzando las piedras a una distancia doble a la alcanzada por los persas. Estos no pueden llegar muy lejos, pues emplean piedras muy gruesas: los rodios, en cambio, saben usar balas de plomo. Si lográramos saber quiénes de entre los rodios tienen hondas, y se las pagáramos; si diéramos también dinero al que quisiera tejer otras y buscáramos alguna otra exención para todo aquel que se presente a manejarlas contra los enemigos, seguramente se presentarían honderos aptos para esta clase de servicios (...) Todos aceptaron este parecer, y aquella noche se logró reunir más de doscientos honderos». Posiblemente, los cuerpos de honderos llegaron a estar tan especializados en Grecia como las unidades de arqueros escitas, como indica el hecho de que los beocios reclutaron honderos en el golfo de Melida antes de atacar Delion 
(Tucídides, Historia de la Guerra del Peloponeso, IV, C, 1), combatiendo de forma coordinada junto a los hoplitas a partir de la segunda mitad del siglo $\mathrm{V}$ a.C. para obtener una irresistible potencia de fuego como en Drilae (Jenofonte, Anábasis, V, 2, 12), intercalando las unidades de hoplitas y arqueros como en el ataque a los Mossynoeci (Jenofonte, Anábasis, $\mathrm{V}, 22-26)$, o empleando el fuego de cobertura de los arqueros para permitir a los infantes asaltar las murallas de una ciudad, como se representa en el Monumento de las Nereidas de Xantos, datado entorno al 400 a.C. (Anderson,1970).

En consecuencia, la honda se emplearía fundamentalmente en los combates en campo abierto, donde además los proyectiles serían fáciles de obtener (en el relato 1 Samuel, 17,40, David se agacha para escoger cinco piedras de características concretas cuando ya ha sido aceptado su deseo de medirse con Goliath), y donde el disparo a bulto tendría mayores posibilidades de obtener resultados al realizarse sobre formaciones cerradas. En su dispositivo táctico al inicio de la campaña de Italia, Aníbal sitúa en primera fila de su ejército a las tropas ligeras y a los honderos baleáricos (Tito Livio, XXI, 55, 2), con los que inicia la lucha hostigando a los romanos que «quedaron cubiertos por una nube de dardos lanzados por los baleares» (Tito Livio, XXI, 55, 6), dispositivo que repite en Cannae el año 216 a.C. (Polibio $3,113,6$ ), siendo muy significativo el hecho de que estas tropas se citen expresamente en las relaciones de la distribución de contingentes que Aníbal realiza antes de dejar el mando del territorio cartaginés en la península Ibérica a su hermano Asdrúbal: «envió a Africa trece mil ochocientos cincuenta infantes de escudo ligero, con ochocientos setenta honderos baleares y mil doscientos jinetes de varias naciones» (Tito Livio, XXI, 21), incluyendo otros quinientos honderos en las tropas que deja bajo el mando directo de Asdrúbal (Tito Livio, XXI, 22), y ello pese a la importancia que confiere a estas tropas, a las que intentará proteger a lo largo de la campaña italiana como soldados de elite irremplazables.

Resta por tanto el arco como arma de mano de empleo a larga distancia más utilizada en la defensa, pese a que Polieno (Estratagemas, V, 48) indica que la honda tiene un alcance mayor que el arco, refiriéndose al combate entre Pirecmes y Esquines del que también hacen mención Pausanias $(\mathrm{V}, 4,2)$ y Estrabón (357c) en una historia legendaria situada en el período de los Heráclidas. Por su parte, Tucídides (Anábasis, III, 16) indica también la superioridad de alcance de la honda con respecto al arco afirmando que los honderos rodios lanzaban sus proyectiles a mayor distancia que los arqueros persas.

Con respecto al empleo del arco en el mundo ibérico, F.Quesada (1989a, 1989b, 1997) ha indicado que no formaría parte habitual de la panoplia del guerrero ibero por tratarse de un arma que hiere a distancia, no siendo éste el tipo de combate, caballeroso y heroico, más apreciado por el mundo ibérico (Quesada,1989a, 320), en el que la nobleza militar reafirma su estatus mediante las luchas individuales heroicas y heroizadas reflejadas en los grandes conjuntos escultóricos de la Alta Andalucía, como Cerrillo Blanco (Porcuna) (Negueruela, 1990) o El Pajarillo (Huelma) (Molinos et alii, 1998), debiendo recordarse que incluso cuando en los relatos homéricos Paris emplea una flecha para alcanzar desde las murallas de Troya a Aquiles, y aunque la acción sea guiada por la mano de Athenea, este proceder no parece correcto a sus contemporáneos, existiendo en el relato homérico otros ejemplos del desprecio que para una sociedad de héroes (léase nobles) tenía el empleo de un arma que alejaba el ideal del combate singular o monomachia. Otros textos, sin embargo, enaltecen el dominio de este arma en la respuesta que Teucro «no es vil el oficio en el que soy maestro» da a la invectiva de Menelao, quien insiste en considerar al arquero a un nivel menor que el hoplita "como te pavonearías si llevases escudo», aunque el primero recuerda la superioridad de su arma «incluso sin, me bastaría contra ti, el armado» (Sófocles, Ajax, 1120-1122).

Pese a ello, en la sociedad heroica por antonomasia, Grecia, el arco se incluye entre la panoplia característica de los dioses como Artemisa o, especialmente, Heracles, o bien en acciones propias de los héroes o de una clase social determinada, como la caza (Snodgrass, 
1967) por lo que no puede considerarse a priori al arco como un arma despreciable sino, por el contrario, un trabajo de especialistas, como se ha indicado supra, con evidentes proyecciones en el orden social.

No obstante, este rechazo al empleo del arco tiene un claro origen de estatus de clase social. Con armas de puño, un noble o un guerrero entrenado será siempre superior a un soldado de leva (campesino armado) manteniendo las diferencias existentes entre ambos también en el uso de la fuerza. El desprecio (y el temor) hacia las armas no nobiliares se documenta asimismo en otros períodos, como en las derrotas de la caballería nobiliar francesa en Crécy (1346) y Agincourt (1415) durante la guerra de los Cien Años frente a los arqueros galeses provistos de arcos largos (long bow), o en la superioridad de los piqueros flamencos en Courtrai (1302) o suizos en Morgarten (1315) y Laupen (1339) frente a la caballería de los reinos europeos durante los siglos XIV y XVI (Montgomery, 1969). Con todo, en la Ilíada se referencian diversos pasajes en los que los combates de los héroes en campo abierto se inician con el empleo masivo del arco y las flechas (XV, 313-314), (III, 76-78), especialmente este último en el que se describe un fuego de barrera: «detuvo las falanges troyanas, que al momento se quedaban quietas. Los aqueos de larga cabellera, le arrojaban flechas, dardos y piedras» (Reboreda, 1998), y debe recordarse que en la Odisea, el reconocimiento de la superioridad del héroe y de su retorno al gobierno de Itaca, se determina por el hecho de que Ulises es el único que puede tensar su arco (XXI), que ha sido enunciado por Penélope, por designio de Atenea, como el símbolo del derecho a su mano y al trono; o que en el Antiguo Testamento, entre las armas que confiere Saúl a David para dirigir a su ejército se encuentra el arco (1 Samuel,18), un arma de indiscutible prestigio en el Próximo Oriente y Egipto. Otros factores como el hecho de que Pisístrato empleara en Atenas durante su tiranía arqueros escitas como fuerza de policía (546-528 a.C.), y que los mismos combatieran junto a los persas en las Guerrea Médicas, o que la última resistencia de los espartanos de Leónidas en las Termópilas (480 a.C.) fuera vencida por la masa de los arqueros persas, pudieron influir sobre el aparente rechazo que el mundo griego muestra ante el empleo de los arcos como arma por parte de los hoplitas. Sin embargo, Atenas disponía ya de un cuerpo de arqueros en Salamina (480 a.C.) y su presencia en el ejército de la ciudad se impuso con rapidez, siendo entrenados ciudadanos atenienses como arqueros a mediados del siglo $\mathrm{V}$ a.C., citándose a partir de esa fecha a los jefes de arqueros o toxarchoi en las fuentes clásicas; los nuevos arqueros alcanzaron un gran prestigio por su actuación en el combate de Esfacteria (425 a.C.) donde contribuyeron a la rendición de un destacamento de hoplitas espartanos (Snodgrass, 1967). No obstante, una cosa muy distinta es la aplicación directa de estos preceptos de forma estricta al campo de la guerra en la cultura Ibérica.

Sin embargo, debe indicarse que el tipo de combate al que se refiere el asedio de una ciudad es el más alejado del sistema de combate o enfrentamiento personal caro al sistema de guerra hoplítico o al mundo ibérico (Quesada, 1997b). En un asalto la masa substituye al hombre, y los combatientes tienen importancia por su número y acciones más que por su valor personal, al ser tanto la defensa como el ataque de la fortificación un esfuerzo bélico de conjunto.

Tito Livio indica que el arma principal de los saguntinos eran los dardos : «(..) al principio rechazaron al enemigo con sus dardos sin dejar un punto seguro para sus trabajos. Después ya no sólo tenían ánimos para luchar con sus dardos desde los muros y desde las torres (...)» (XXI,7), e incluso el propio comandante cartaginés fue herido por un proyectil: "Aníbal, que se acercó demasiado descubierto a la muralla, cayó gravemente herido por una flecha que le traspasó la pierna, fue tanto el espanto y confusión a su alrededor que no faltó mucho para que abandonasen las obras y manteletes» (XXI,7) de las muchas que le lanzaban desde la muralla: «Como si las flechas ni los proyectiles no pudieran herirle o matarle» (Silio Itálico, Punica,I,428-429). La cuestión básica para la interpretación de estos 
textos radica en la traducción del término dardos (missilibus) en la obra de Tito Livio; si no se trata de flechas (o proyectiles de honda) sólo puede referirse a armas arrojadizas de asta para las que existen nombres específicos, como la lanza, el pilum, el soliferrum, u otro tipo de jabalinas menores como la trágula que es el término empleado por Tito Livio para nombrar el arma que hiere a Aníbal (a diferencia de la incorrecta traducción citada de las FHA que emplea el de flecha). El problema de la trágula es que se trata de un tipo de jabalina muy característica de la Galia, descrita en primera instancia por Cayo Julio César en el Bello Gallico (Feugère,1993), de donde tomaría el término Tito Livio, siendo difícil pensar que el escritor de Padua quisiera referirse a una trágula en sentido estricto, y empleándolo por ser el que más se aproximaba a la realidad de la tradición que había perdurado hasta la fecha sobre la herida de Aníbal, que probablemente fuera Polibio, aunque su obra no se cita, aunque sí el hecho de que Aníbal estaba presente en todos los puestos del asedio. Si todos los proyectiles citados bajo el concepto de dardos fueran armas de asta se plantean evidentes problemas de volumen de ítems y suministro para prolongar una defensa durante un período de tiempo prolongado, por lo que lo más lógico, en nuestra opinión, es incluir a la flecha dentro de la categoría de dardos.

Aunque existe un vacío en la documentación iconográfica y arqueológica por lo que respecta a los arcos y las puntas de flecha entre los siglos VI y II a.C. (Quesada, 1989), el empleo de puntas de flecha en la península Ibérica se documenta por ejemplo en el poblado de La Rábita (Guardamar del Segura) (Azuar,Rouillard,Gailledrat, Moret, Sala,Badie, 1998) durante el siglo VI a.C., donde se localizan en las estancias adjuntas a las fortificaciones, habiendo recogido F. Quesada (Quesada, 1989), (Quesada, 1998) los ejemplares anteriores; y el combate entre arqueros en el vaso de los navíos del poblado de Sant Miquel (Llíria), aunque otros autores, como F.Quesada, opinan que no se trata de arcos sino de escudos vistos de perfil (Quesada, 1988). Los arcos deberían ser tanto del tipo simple como compuesto, dado que éste último es el propio del área del Próximo Oriente, y como tal el que sería traído a la península por fenicios y púnicos (Ramón,1983). Los arcos se emplearían tanto para el tiro individual como para el fuego en masa o de cobertura, buscando causar los mayores estragos por el número de los proyectiles, como se describe en varias ocasiones «quedaron cubiertos por una nube de dardos lanzados por los baleares» (Tito Livio, XXI, 55, 6), mientras que en otras: «marcharon primero a través de las asperezas, sin más obstáculo que los del camino. Después, llegados ya al alcance del tiro, una fortísima lluvia de proyectiles de todo género cae sobre ellos; contestan a su vez con piedras que esparcidas por doquier y arrojadizas casi todas el lugar les ofrece (...) pese a lo difícil del ascenso y a que los dardos y las piedras los cubrían casi, su práctica en escalar muros y la obstinación de su ánimo hicieron llegar a unos cuantos a la cima (...)», (Tito Livio, XXVII, 18).

Un grupo de arqueros bien entrenado podía crear un fuego de barrera denso y preciso ante las murallas, puesto que la cadencia de tiro podía alcanzar los 10 o 12 disparos por minuto, para un alcance máximo de $400 \mathrm{~m}$ y efectivo (tiro de precisión) no superior a los $50 \mathrm{~m}$. Estudios teóricos realizados sobre diversos tipos de arcos simples y compuestos indican que la velocidad de salida de las flechas en los arcos simples sería de $30-35 \mathrm{mps}$, mientras que en los arcos compuestos podría alcanzar los 40-47 mps lo que le confiere un mayor poder de penetración (Bergman, McEwen,Miller, 1988), (Miller,McEwen,Bergman, 1986). El empleo de un arma de este tipo facilitaría crear una amplia zona batida por el fuego de barrera ante los muros. El hecho de que Publio Cornelio Escipión debiera incluir durante sus campañas en la península Ibérica un grupo de arqueros (sagitarii) en cada centuria, siendo según Tito Livio (XXVII, 38) la fecha del 207 a.C. la primera en la cuál los romanos introdujeron este arma en su ejército, muestra la necesidad de contrarrestar la profusión del empleo del arco entre sus enemigos, cartagineses e iberos (Feugère, 1993). La cita de Tito Livio es más interesante por lo que sugiere que por el dato concreto que aporta: el envío por parte de Cayo 
Mamilio de 3000 arqueros y honderos desde Sicilia a Italia para combatir a los cartagineses. Como se ha indicado, se trata de la primera mención en las fuentes clásicas de la inclusión de arqueros en el ejército romano, pero tanto por el número de los mismos como la forma de citarlos, la información es tratada de forma muy poco relevante, lo que permite suponer que los arqueros eran empleados por Roma con anterioridad a esta fecha, puesto que al significar su presencia una transformación fundamental en el concepto de comprender el combate por el aumento de la densidad de fuego, la primera mención a este hecho tendría, lógicamente, que haber sido expuesta de forma diferente.

Debe reflexionarse también sobre la composición del contingente humano que forman los 3000 arqueros y honderos citados. En el mismo texto (Tito Livio, XXVII,38) se indica que Publio Cornelio Escipión envía a Italia diversos destacamentos de caballería e infantería auxiliar y legionaria, mencionando expresamente a los iberos; en el caso de Sicilia no existe esta precisión, por lo que ha de suponerse que el dato no era necesario porque el lector tendría muy claro de qué tipo de soldados se trataba. Admitiendo la dificultad de que fuesen romanos por los motivos ya indicados, la tropa reunida por Cayo Mamilio tenía que ser indefectiblemente mercenaria, pudiendo ser los funditores baleares o bien griegos (rodios, acaios o acarnanios) y los sagitarios númidas o cretenses como los empleados por Cayo Julio César (Bello Gallico, II,7), aunque en la propia Sicilia, Gelón de Siracusa contaba el año 480 a.C. con un cuerpo de 2000 arqueros de procedencia diversa (Snodgrass,1967).

\section{LA DEFENSA MÓVIL O DEFENSA OFENSIVA.}

En consecuencia, en la guerra, la forma defensiva no es un mero escudo, sino un escudo que va acompañado por golpes asestados hábilmente.

\section{Clausewitz.}

Los ejemplos indicados hacen referencia a una concepción defensiva de tipo estático, en la que todo el planteamiento pivota en función de la línea de muralla al concentrar los esfuerzos de la defensa en el mantenimiento de la misma, puesto que su pérdida significa la irrupción del enemigo en el interior de la población y la derrota subsiguiente por la inferioridad ante el superior número de atacantes y la desmoralización de los defensores al caer el principal bastión de la ciudad. No obstante, existen otras tácticas de defensa, denominadas móviles o agresivas, en las que los sitiados, además de mantener la cobertura de las murallas, efectúan salidas contra el asaltante para quemar sus máquinas, desbaratar sus posiciones y, en el mejor de los casos, hacerle retroceder, como describe Cayo Julio César respecto del asedio de Masalia: «los sitiados irrumpen fuera de las puertas, y gracias a un gran viento favorable, prenden fuego a los trabajos de aproximación. El viento inflamó la lumbre de tal modo que a un mismo tiempo el terraplén, los plúteos, la tortuga, la torre y los aparatos de artillería, quedaron envueltos en llamas, y todo ello se consumió antes de que pudiera advertirse de qué modo había sucedido» (Bello Civile, II, XIV, 1-2).

Este planteamiento táctico es descrito por Eneas el Táctico en los siguientes términos: «en otra ocasión, los asediados sorprendieron al enemigo, con una salida secreta, de la siguiente manera: construyeron un muro delante de las puertas a la vista del enemigo; a continuación, en el lugar que era particularmente propicio para un ataque enemigo, desplegaron una pequeña vela y la recogieron después de algún tiempo, de manera que, en un principio, asombrara a los enemigos, pero después, dado que la maniobra se repetía muchas veces, no le dieron importancia. Una noche, los habitantes de la ciudad, tras hacer en el muro una abertura del tamaño deseado y construir una falsa estructura en su lugar, desple- 
garon una vela. Después de esperar la ocasión propicia, efectuaron una salida y atacaron por sorpresa a los enemigos» (Poliorcética, XXIII, 4-5), un tipo de acción que llevan a cabo los saguntinos : «sino para caer sobre los destacamentos y fortificaciones de los enemigos, $y$ en estos repentinos combates no caían más saguntinos que cartagineses» (Tito Livio, XXI,7) en varias ocasiones: "Aníbal estaba alli donde el ejército de los sitiados había intentado una salida por sorpresa» (Silio Itálico, Punica,I, 426-429); «Entonces, los guerreros saguntinos, enmudecidos por esta muerte heroica, avanzan para impedir que el fiero vencedor pudiera hacerse con las famosas armas de Murrus y con su cadáver» (Silo Itálico, Punica, I, 518-521); «los hombres por su parte irrumpen en la noche contra los destacamentos cartagineses, entregados aún al sueño y sin ninguna sospecha» (Apiano, Iberia, 12), pero que es común a otras tribus o poblaciones asediadas, como los lacetanos: «El mayor número de sus auxiliares estaba formado por suesetanos; a éstos mandó empezar el ataque a la muralla. Cuando reconocieron los lacetanos sus armas y sus enseñas, recordando cuántas veces habían saqueado impunemente sus campos, cuántas en batalla formada los habían derrotado y dispersado, abriendo de repente la puerta, irrumpieron todos contra ellos» (Tito Livio, XXXIV, 20).

Tan común debía ser la táctica de la salida que incluso cuando Aníbal decide dar descanso a sus tropas durante el asedio de Sagunto, mantiene una guardia en las obras de sitio: «Aníbal, viendo que los combates y los trabajos habían agotado a sus soldados, les concede un descanso de algunos días, después de establecer puestos de guardia en los manteletes y otras obras» (Tito Livio, XXI, 11).

La realización de salidas contra las tropas que asedian un recinto fortificado precisa del conocimiento previo de este tipo de estrategia para poder ser realizada, puesto que es un recurso táctico que no puede improvisarse. Para poder desarrollar una defensa ofensiva se precisa de un sistema de fortificaciones que incluya poternas en el flanco de las torres protegidas por un sistema avanzado de muros (epikampion) inscritos en una proteichisma. Filón de Bizancio indica que "para efectuar las salidas con tranquilidad, era menester que hubiese muchas poternas en los flancos. De éstas unas contaban con junturas articuladas y otras con puertas que se aseguraban por medio de cerrojos. Las poternas que se abrían en los flancos derechos estaban reservadas para las salidas, las de los flancos izquierdos para los regresos». A diferencia del relato de Eneas el Táctico (Poliorcética, XXIII, 4-5) en la que los defensores de la ciudad han de recurrir al derribo de una parte del muro para poder realizar la salida, en la península Ibérica el concepto de la poterna se encuentra perfectamente integrado en el planteamiento constructivo de las fortificaciones a partir del siglo V a.C. El trazado de los poblados del nordeste peninsular incluye la asociación torre-poterna-muro avanzado, probablemente derivada de las soluciones técnicas aplicadas en el sistema defensivo de Emporion entre el siglo V y la segunda mitad del siglo III a.C. (Sanmartí, Nolla, 1986), (Sanmartí, Castanyer, Tremoleda, 1988 y 1991), (Sanmartí, Castanyer,Santos,Tremoleda, 1996) siendo ejemplos significativos de la misma las obras avanzadas de los poblados del Puig de Sant Andreu (Ullastret) y Turó del Montgrós (El Brull) (Gracia, 1997). Pese a la tesis que ha indicado el hecho de que las obras avanzadas eran tan sólo una copia de prestigio por parte de las elites locales de las obras monumentales de Emporion, creemos, tal y como hemos indicado en anteriores trabajos, que la construcción de un sistema defensivo específico implica un claro conocimiento de sus posibilidades de empleo, y, al mismo tiempo, una necesidad próxima o futura de utilizarlo. La salida debe considerarse por tanto como una práctica común en la estrategia militar del mundo ibérico, siendo su principal objetivo la destrucción de las obras de contrafortificación y las máquinas de guerra del asaltante. 
EL ATAQUE A LA CIUDAD.

\begin{abstract}
Ataque ciudades tan sólo cuando no haya otra alternati$v a$, porque preparar grandes corazas y furgones y alistar armas y los equipos necesarios requieren lo menos tres meses; amontonar rampas de tierra contra las murallas requiere tres meses más. El general que no pueda controlar su impaciencia ordenará a sus tropas que suban en tropel las murallas como hormigas. Como resultado, un tercio de esas tropas perderá la vida sin tomar la ciudad. De ahí que atacar ciudades sea una calamidad.
\end{abstract}

Sun Tzu.

Las obras exteriores de las fortificaciones ibéricas tenían que estar complementadas por la construcción de fosos. Pese a que tan sólo han sido excavados los correspondientes a las fortificaciones de Turó de Montgrós (El Brull) (Molist,Rovira,1991) y Les Toixoneres (Calafell) para cronologías del Ibérico Pleno, otros poblados como Els Vilars (Arbeca) (Junyent, Lafuente, López, 1994) muestran perfectamente el conocimiento de este elemento defensivo en el área del nordeste desde el siglo VII a.C. en relación con sistemas de torres y murallas complejas. El fundamento teórico del foso es el mismo que el de la proteichisma: mantener al enemigo alejado de la muralla, debiendo tener, según los tratados de Filón de Bizancio, la mayor profundidad posible y una anchura mínima de 70 codos (c. $32 \mathrm{~m}$ ) para impedir que las máquinas de guerra pudieran ubicarse en posición de tiro contra las fortificaciones. La existencia de un foso constituye asimismo una excelente defensa contra las tareas de zapa realizadas por el asaltante, tal y como indica Eneas el Táctico (Poliorcética, XXXVII, 1): «He aquí como hay que impedir los trabajos de quienes construyen minas. Si tenéis la certeza de que están construyendo minas, hay que excavar una fosa lo más profunda posible en la parte exterior de la muralla con la finalidad de que la mina desemboque en ella y queden al descubierto los zapadores», dificultando que éste inicie la perforación de sus túneles cerca de la base de los muros, debiendo comenzar la excavación a mucha distancia (y a gran profundidad) para sortear el obstáculo; ambos hechos facilitan las tareas de contrazapa o contraminado, especialmente la detección e incendio de los túneles.

Las especiales características constructivas de las fortificaciones ibéricas, realizadas con bloques de piedra de diferente tamaño y talla no isodoma unidas con arcilla pero no con mortero, provocan que la distribución del esfuerzo o carga sea irregular en las diferentes partes de un muro. Así, la fuerza de un proyectil se concentra en el punto de impacto del mismo si el muro es de piedra, mientras que si es de adobe o tapia se reparte uniformemente por toda la sección. Al chocar un proyectil, o golpear la cabeza de un ariete contra un muro pétreo, los bloques basculan provocándose el hundimiento del muro o de la torre contra la cual se actúa, por lo que en los tratados de Filón de Bizancio y Eneas el Táctico se recomienda la construcción de muros empleando como material básico la tierra. Al mismo tiempo, la mejor defensa contra el tiro de los proyectiles de catapulta es la construcción de muros apuntados cuyo vértice se oriente hacia la trayectoria del tiro de las máquinas, provocando un efecto de deflación del proyectil al reducir el frente del muro, y reduciendo al mínimo la fuerza del impacto del mismo. Fortificaciones como las torres pentagonales de los poblados del Castellet de Banyoles (Tivissa) (Pallarés, 1983-1984), (Gracia, Munilla,Pallarés, 1991) o La Serreta (Alcoy) (Llobregat, 1995) se construyeron expresamente con este fin, al tiempo que la remodelación de otras construcciones anteriores, como la torre de la puerta 1 del poblado del Puig de Sant Andreu (Ullastret) (Gracia, 1997) o la disposición de bastiones triangulares ante las torres de la Muralla Frigoleta del mismo poblado tuvieron sin duda su origen en los conoci- 
mientos de los efectos de la balística sobre las murallas. A modo de comparación es significativo recordar que tras el desarrollo de la artillería de sitio basada en el empleo de la pólvora durante el siglo XVI, las modificaciones en el trazado de las fortificaciones en Europa occidental a partir de los modelos teóricos introducidos por Sebastien Le Prestre, marqués de Vauban (1633-1707), adoptasen el trazado en estrella que presentaba frentes angulosos y glacis al tiro de los cañones, un sistema arquitectónico que se mantuvo en vigor hasta la segunda mitad del siglo XIX con la superación de la guerra de sitio.

Por ello, la mayor parte de las superestructuras de las murallas de las fortificaciones ibéricas se construían con adobe o tapia, siendo especialmente destacables las torres del poblado del Castellet de Banyoles (Tivissa) (Pallarés, 1983-1984), (Gracia, Munilla, Pallarés, 1991), en cuyo sistema defensivo se introdujo una cloaca para facilitar la evacuación de las aguas del interior del recinto, preservando de este modo a las construcciones de la humedad, que constituye su mayor inconveniente. Un claro ejemplo de éste último aspecto es la substitución de los muros de adobes de la fase III del oppidum de Heuneburg (Baden-Würtenberg, Alemania) durante el siglo VI a.C., obra de un ingeniero de origen mediterráneo, por el sistema clásico de muros de madera y piedra adaptado a la climatología de Europa central. La tapia y el adobe en la península Ibérica, empleados desde el siglo VIII a.C. en el área del Levante, se generalizaron hasta el punto de ser recogidos por su fama en los textos de Plinio: «En Africa y en España, no hay muros de tierra llamados muros de molde, porque puestos entre dos paredes se moldean más que se construyen?. Se conservan durante siglos, inatacables por la lluvia, por el viento, por el fuego, más fuertes que cualquier cemento» (Nat. Hist, 35, 169). El empleo de la tierra en las fortificaciones alcanzó su máximo exponente con la construcción de muros definidos a partir de dos paredes de piedra separadas por una distancia de 20 pasos (circa $6 \mathrm{~m}$ ) la zona interior de los cuales se rellenaba con tierra apisonada; una muralla de este tipo, según Vegecio (Epit.Rei.Mil,III,4) podía llegar a ser inmune a los arietes: "Ningún muro reforzado con tierra puede romperse por el ariete y en el caso de que fuese derrumbada la piedra, la masa de tierra que fue apisonada en el interior de las paredes resiste como un muro a los asaltos».

La zapa de los muros fue el recurso empleado por Aníbal para conquistar Sagunto: «entonces, Aníbal, creyendo llegado el momento, lanzó quinientos africanos a socavar con picos el pie de la muralla. No era difícil este trabajo, puesto que el cemento no estaba endurecido con cal, sino que las piedras estaban unidas con barro, según la costumbre antigua. De este modo se derrumba un espacio de muro más extenso que el que era percutido, y por las brechas los grupos de sitiadores entraban en la ciudad» (Tito Livio,XXI,11), versión que recoge posteriormente Zonaras: «mientras los saguntinos pelean con todas sus fuerzas contra los que ven, creyendo ser los únicos, los otros excavan la muralla y fuerzan la entrada» $(8,21)$.

El texto de Tito Livio es incompleto o inexacto, por cuanto el trabajo de los zapadores se realizaría sin protección contra el fuego de barrera de los defensores, aún y cuando se indique que una torre de asedio ha conseguido desalojar a los defensores de la parte alta de los muros: «una torre móvil que en altura vencía las fortificaciones todas de la ciudad. Y ésta, dispuesta a conveniente distancia, barrió con las catapultas y ballestas dispuestas en todos sus tablados los defensores de la muralla» (Tito Livio, XXI, 11), y, especialmente, del modo descrito no se atacarían los cimientos de la muralla sino tan sólo la base del muro a nivel del ras de tierra, siendo éste un trabajo muy complejo por cuanto los cimentos de las fortificaciones, siguiendo las tesis poliorcéticas, se asentaban directamente sobre la roca para evitar en lo posible los efectos del trabajo de zapa.

Al describir el mismo hecho, Silio Itálico indica que los cartagineses emplearon una formación de tortuga con sus escudos (testudinis armis) para acercarse al pie de la muralla: «Por último, uniendo sus escudos, los cartagineses forman una tortuga con las escamas cerradas, es un muro que avanza, un reducto al abrigo del cual zapan secretamente la muralla 
que se hunde, abriendo la ciudad. El lienzo del muro cede, y con un gran ruido, los muros, obra de Hércules, se derrumban, los enormes bloques se dislocan y elevan hasta el cielo un potente rugido» (Punica I, 364-371). El concepto de la tortuga indica que los zapadores trabajaban protegidos por manteletes a cubierto del fuego de barrera lanzado por los defensores, pero en ningún caso puede aceptarse que el trabajo de zapa fuese lo suficientemente rápido como para que con la simple protección de los escudos los soldados pudieran excavar la base de la fortificación, ni aún en el caso de que se tratara de hundir una parte de la muralla ya golpeada con otro tipo de máquinas, puesto que cualquier tarea de este tipo es lenta, tal y como muestra el hecho de que tras la partida de Aníbal desde el asedio de Sagunto para luchar contra la sublevación de los oretanos y carpetanos, su substituto, Maharbal, continúe las tareas de asedio obteniendo algunos éxitos: «sostuvo algunos combates favorables y arruinó con tres arietes una cierta longitud de muro, y pudo mostrar a Aníbal, a su llegada, todo el suelo sembrado de recientes ruinas» (Tito Livio, XXI, 11).

Probablemente, los trabajos de zapa se realizaban bajo la protección de manteletes o testudos con armazón de madera, citados repetidamente en los relatos del asedio (Tito Livio, 21,7), en una acción combinada similar a la que provocó la toma de Masalia, en la que se empleó una protección móvil o músculo: «cuando los sitiados se percatan de ello, cambian de idea: prenden fuego a barriles repletos de resina y pez y los despeñan desde la muralla hasta el músculo; resbalan, oscilan, y ya caídos a ambos flancos, son separados por los nuestros mediante perchas y horquetas. Entre tanto, por debajo del músculo, los soldados socavan con barretas los bloques más bajos de la torre del enemigo, en los cuales descansaban los cimientos (...) removidas ya muchas piedras de las que yacían debajo de su torre, se produce la ruina repentina de una parte de dicha construcción, mientras la otra parte ya se inclinaba en seguida» (Bello Civile, II, XI, 2-4), descripción muy similar a la que causó la ruina definitiva de Sagunto: «cuando toda la ciudad estaba aterrorizada por este espectáculo, se oye un nuevo tumulto por el lado de la ciudadela. Una torre mucho tiempo combatida se había derrumbado, y por sus ruinas apareció una cohorte de cartagineses en pleno ataque» (Tito Livio, XXI, 14).

Filón de Bizancio describía los testudos o tortugas construidos con ramas de mimbre entrelazadas con las aristas en la zona exterior y recubiertas de pieles para proteger a la madera del fuego, su principal enemigo según la descripción de Eneas el Táctico (Poliorcética, XXXIII). En ocasiones, estos artefactos se montaban sobre ruedas para permitir su avance mediante el impulso de los soldados que llevaba en su interior.

Con todo, el sistema más empleado para batir los muros de una ciudad era el ariete cubierto, máquina desarrollada en el Próximo Oriente durante las campañas militares del imperio neoasirio, del que existían diversos modelos según muestran los relieves de los palacios de Tiglat-Pileser en el que se muestra un ariete de doble punta actuando bajo la protección de arqueros, y en el de Senaquerib en que un ariete móvil de una punta actúa contra torres y murallas (Healy, 1994). Diodoro (XII, 28) indica que el ariete fue empleado por vez primera en Grecia durante el asedio de Samos por los atenienses el año 440 a.C., siendo su inventor Artemón de Clazómene, ingeniero al servicio de Pericles (Plutarco, Pericles, XXVII, 3), aunque diversas fuentes nombran el empleo de armazones de madera para aproximarse a los objetivos, como en Aeolis (Jenofonte, Hellenica,III, 1, 7). El ariete, protegido por un mantelete o cubierta reforzada con pieles para aumentar su espesor e impedir la expansión de líquidos inflamables, y sobre el que se vertía agua para impedir la combustión, consistía en una estructura de balancín, dotada o no de ruedas, que podía golpear repetidamente un punto del muro hasta conseguir su desestabilización. El ejército cartaginés empleó profusamente los arietes contra Sagunto: «contra él mandó instalar los manteletes para poder por ellos aproximar los arietes a las murallas» (Tito Livio, XXI, 7); «y por muchos puntos, a pesar de que había pocos lugares aptos para ello, se empezaron a instalar máquinas y moverse arie- 
tes» (Tito Livio, XXI, 8); «así ya los arietes golpeaban los muros y muchas partes estaban ya quebrantadas. Por un lado una larga brecha había dejado al descubierto la ciudad; después tres torres y todo el lienzo de muralla intermedio se había derrumbado con un estrépito inmenso» (Tito Livio, XXI, 8), consiguiendo, según los escritores clásicos, derribar buena parte de los muros ya desde los primeros momentos del asedio, sin conseguir, no obstante, que estos éxitos parciales se viesen coronados por la conquista de la ciudad.

Al mismo tiempo que el ariete era introducido por los cartagineses en el Mediterráneo central, hasta el extremo de que Marco Vitrubio Polion les confiere el mérito de su invención (De Architectura,X, 13, 1), se desarrollaron las técnicas para dificultar su empleo y la expugnación de los muros. Eneas el Táctico indica las formas de lucha contra ellos: «se deben preparar, asimismo, las protecciones contra las máquinas, el ariete y otros ingenios del mismo género (...) $Y$, cuando el ariete esté derribando la puerta o alguna otra parte de la muralla, se debe coger la cabeza del ariete con una cuerda, para evitar que la máquina pueda seguir golpeándola. Hay que tener preparada una piedra, de un tamaño suficiente como para llenar un carro, con el objeto de que, al soltarla, caiga sobre el trépano y lo rompa; hay que dejar caer la piedra desde vigas que sobresalgan sujetas por cangrejos» (Poliorcética, XXXII,3-5), que no son originarias de Grecia puesto que este sistema se encuentra representado en los relieves de Nimrud correspondientes al reinado de Senaquerib (883-859 a.C.). Estas técnicas defensivas no aparecen reflejadas en las fuentes clásicas relativas a la península Ibérica, aunque sí lo están las medidas que deben tomarse para paliar el hundimiento de una parte de las fortificaciones.

En el momento en que una sección del muro era derribada, la acumulación de material de construcción que ocupaba el lugar continuaba sirviendo como base para la defensa de la ciudad: «los restos de la muralla que se habían encarnizado a demoler se elevaban como un muro entre los dos ejércitos, pero conservando su ardor tanto uno como el otro, continuaron batiéndose en medio de los escombros» (Silio Itálico, Punica, I, 372-374), aunque el mejor sistema para restañar los daños causados por los arietes es la construcción de un nuevo muro en el interior de la plaza asediada que substituya al anterior: «si las puertas son incendiadas, hay que llevar madera y arrojarla para hacer un fuego todavía mayor, hasta que podáis excavar dentro una fosa y construir un muro defensivo con lo que tengáis a mano; si no hay materiales a disposición, derribad las casas más cercanas» (Poliorcética, XXXIII, 3); "contra la caída de la muralla hay que excavar un foso interior, para evitar que puedan entrar; $y$ simultáneamente, hay que levantar un contramuro construido en el lugar que ha sido destruido, antes de que caiga, en el caso de que no se les pueda detener por otro procedimiento (Poliorcética, XXXII, 12). Esta solución es la adoptada por los defensores de Sagunto cuando las máquinas púnicas consiguen romper el perímetro defensivo de la ciudad: «los saguntinos si descansaron de la lucha por algunos días, no siendo atacados ni atacando ellos, no por esto cesaron de trabajar ni de día ni de noche, hasta levantar una nueva muralla por aquella parte que al derrumbarse dejara al descubierto la ciudad» (Tito Livio, XXI, 11); «los saguntinos, por su parte, construyen una muralla interior por la parte de la ciudad no perdida» (Tito Livio, XXI,11), restañando con ello los daños causados por la acción de las máquinas púnicas, y prolongando la resistencia. La aplicación de los preceptos de Eneas el Táctico sobre la construcción de muros interiores tiene un excelente ejemplo en el asedio de Platea por los lacedemonios (Tucídides, Historia de la Guerra del Peloponeso,II, LXXVI, 3-4).

La táctica de construir nuevas murallas que cierren perímetros de defensa cada vez más reducidos en el interior de la ciudad, supone un intento de mantener la lucha en la confianza de que un factor externo permita el desbloqueo de la plaza, puesto que si bien la resistencia se prolonga y se optimizan las fuerzas de los defensores al acortarse la longitud de los puntos a cubrir por los mismos, también posibilita que el esfuerzo de los sitiadores se concentre en determinados puntos imponiendo la fuerza del número. 
Si las catapultas, balistas y arietes constituyen una parte importante de la panoplia de asedio a partir del siglo IV a.C., el arma determinante es la torre móvil, empleada en el Mediterráneo occidental por vez primera en el asedio de Selinunte por el ejército púnico y posteriormente en Mothia por Dionisio I de Siracusa, aunque se documenta desde el siglo IX a.C. en la iconografía asiria junto al ariete móvil. Concebida como respuesta al problema básico de los sitiadores, eliminar el fuego de barrera de los defensores que impide la aproximación de la infantería a los muros, las torres debían sobrepasar en altura las murallas de la ciudad y conseguir el repliegue de los soldados parapetados sobre los muros y las torres mediante el empleo de una gran potencia de fuego que incluía la instalación de máquinas en los diversos pisos de las mismas. Probablemente, el ingenio más colosal de este tipo fue la helepolis construida por Epímaco de Atenas para Demetrio Poliorcetes durante el fallido sitio de Rodas el año 304 a.C., una torre móvil de $43 \mathrm{~m}$ de altura y $22 \mathrm{~m}$ de lado en su base, provista de ruedas de 4,6 m de diámetro, que montaba múltiples catapultas en sus nueve pisos.

Las respuestas contra las torres móviles eran múltiples, y por ello poco definitivas, variando desde el empleo del fuego para intentar quemarlas hasta el minado del terreno que se extendía ante los muros para impedir su progresión (Poliorcética, XXXII, 8). Con todo, la respuesta más empleada era la elevación por medios de fortuna de la altura de las murallas para impedir que las torres de asedio móviles pudieran dominar la parte superior de las defensas de la ciudad. Esta técnica, descrita en el asedio de Masalia (Bello Civile, II,IX) no se refleja en los relatos sobre la defensa de las ciudades peninsulares, especialmente durante el asedio de Sagunto, pero debe inferirse que los saguntinos conocían diversos métodos de lucha contra las torres móviles por cuanto Aníbal emplea torres móviles cuya altura sobrepasa la de las murallas de la ciudad desde el inicio del asedio (Tito Livio, XXI, 11), y sin embargo, el asedio se extendió por espacio de ocho meses según Tito Livio (XXI, 15) y Zonaras $(8,21)$, lo cuál es ilógico si se entiende que desde el momento en que las torres cobran ventaja sobre las fortificaciones, a los zapadores les es relativamente sencillo abrir las brechas para el asalto de la infantería.

La táctica del asalto no es general sino que se aplica en zonas concretas, teniendo como fin disminuir paulatinamente el perímetro defensivo de la ciudad. De este modo, los cartagineses ocupan sucesivamente diversos sectores: "por esta brecha se creyeron ya los cartagineses dueños de la ciudad; por ella, como si un muro protegiese a unos y otros, corrieron los dos bandos a la lucha (...) los saguntinos oponían sus cuerpos en defensa de su ciudad desmantelada, sin retroceder un pie para que el enemigo no ocupe el terreno abandonado» (Tito Livio, XXI,10), "por las brechas los grupos de sitiadores entraban en la ciudad. Se apoderan de un lugar elevado, y trasladando allí ballestas y catapultas, la rodean de un muro para tener así un castillo dentro de la misma ciudad, a modo de una ciudadela, dominándola toda» (Tito Livio, XXI, 11-12), pero no consiguen hacerse con el control de la ciudad, ya que los defensores aplican la táctica de ir aislando los sectores perdidos reconstruyendo sucesivamente el perímetro mediante la aplicación de conceptos de defensa en profundidad: «los saguntinos, por su parte, construyen una muralla interior por la parte de la ciudad aún no perdida. De uno y otro lado trabajan y luchan con la más grande energía; pero en su defensa los saguntinos reducen cada día la ciudad» (Tito Livio, XXI, 11), como indica Eneas el Táctico: «si los asaltantes tomaran una o dos posiciones, el resto quedaría en posesión de sus adversarios; no obstante, si ocuparan todas, al quedarse bloqueados y divididos, se encontrarían en situación de inferioridad respecto a las fuerzas reagrupadas de sus adversarios, a menos que en cada cuerpo de ejército sobrepasaran a la totalidad de los ciudadanos» (Poliorcética, II, 8).

Pese a que el empleo de máquinas de guerra supone la forma más sofisticada de expugnar las fortificaciones, el sistema más utilizado (a la par que el más antiguo) continuaba siendo la instalación de escalas de fortuna por la que los soldados más diestros o temerarios 
ascendían hasta poner pie en las murallas. Tanto en los asedios de Cartago Nova como de Orongis se cita el empleo de las mismas destacándose su inestabilidad y los medios empleados para hacerlas caer. Los defensores de Orongis muestran un elevado conocimiento de las técnicas para oponerse a ellas puesto que: «incluso si alguien conseguía enganchar las escalas al muro era derribado con horcas construidas al efecto o, desde arriba, le echaban encima garfios de hierro de forma que corrían el peligro de ser levantados en vilo hasta lo alto del muro» (Tito Livio XXVIII, 3).

La expugnación de la ciudad no depende tan sólo de la superioridad numérica y logística del asaltante, sino también de la aplicación de otras tácticas en el caso de que el asedio se prolongue. Aníbal lleva a cabo el bloqueo de Sagunto para impedir que los asediados reciban ayuda y aprovisionamientos, controlando a las tribus del interior (Tito Livio XXI, 11) y rechazando los argumentos de los legados romanos (Tito Livio XXI, 11), mediante una serie de campamentos que, según los textos de Apiano (Iberia, 10) incluían un foso y una valla: "pasando el Ebro con todas sus tropas, se puso a devastar la región y a emplazar sus máquinas contra la ciudad; no pudiendo tomarla por asalto, la rodeó con una fosa y de una valla, con numerosos destacamentos de guardia, y volvió a ella después de un tiempo», aunque en relación con esta descripción debe recordarse que la obra de este escritor está plagada de errores y de adaptaciones de otros hechos, puesto que la descripción por él realizada podría perfectamente aplicarse a los sistemas de asedio romanos del período final de la república, especialmente las fortificaciones de Cayo Julio César en Alesia, siendo también la táctica empleada por Lucio Escipión contra Orongis: «rodeó la ciudad de foso y doble empalizada, $y$ dividió el ejército en tres cuerpos» (Tito Livio, XXVIII, 3). El bloqueo conduce al hambre y a la desesperación a los asediados según reflejan Tito Livio (XXI, 11), Apiano (Iberia, 12), Floro $(1,22,3)$ y Orosio $(4,14,1)$, debilitando su fuerzas física y convicción moral, y precipitando por ello la caída de la ciudad.

\section{CONCLUSIONES}

Pese a que en las fuentes clásicas se citan repetidamente asedios de ciudades en la península Ibérica, ningún relato es tan detallado como el correspondiente a la toma de Sagunto, por lo que cabría pensar en él como en un hecho extraordinario, y en la potencia de sus fortificaciones y conocimientos tácticos de sus habitantes como el resultado de los especiales contactos comerciales con las colonias y factorías foceas occidentales, aunque es asimismo posible que las referencias a este asedio concreto en la obras de los escritores griegos y latinos se deban a la importancia política que el mismo tuvo como casus belli de la Segunda Guerra Púnica. No obstante, y como hemos indicado, existen indicios que permiten apuntar la hipótesis de que el conocimiento poliorcético estaba muy extendido entre las tribus ibéricas a fines del siglo III a.C., y que éstas conocían los sistemas fundamentales de defensa contra el empleo de máquinas de guerra. Si los defensores de Sagunto no hubieran conocido los diversos tipos de máquinas de guerra que el ejército púnico desplegó para tomar la ciudad podía perfectamente haberse producido el mismo pánico que permitió a los cartagineses avanzar rápidamente en Sicilia durante su segunda campaña contra las ciudades griegas de la isla, ocupando sucesivamente Himera, Selinunte y Agrigento entre el 409 y el 405 a.C.

Es evidente también que Aníbal debió extraer serias conclusiones de su prolongado asedio contra la ciudad. Respecto a las pérdidas sufridas Polibio $(3,33,5)$ y Tito Livio (XXI, 21-22) indican que en la distribución de fuerzas que Aníbal realiza en la primavera del 218 a.C. se asignan 15.920 hombres a Africa, 15.200 quedan de guarnición en la península bajo el mando de Asdrúbal y 102.000 cruzan con él el Ebro; la suma de estas cifras arroja un total de 133.120 soldados, con lo que si tenemos en cuenta que las unidades se habían reforzado 
con las levas de los reclutadores púnicos realizadas al final del invierno, significa que el general cartaginés pudo perder en el asedio de Sagunto casi un tercio de los 150.000 hombres que Tito Livio (XXI, 8) indica que formaban el ejército cartaginés al inicio del sitio. La ruta que tomó para dirigirse hacia la península Itálica evitó cuidadosamente los poblados fortificados próximos a la costa puesto que no podía retrasar su marcha con continuos asedios ante fortificaciones que como las de Burriac (Cabrera de Mar), Puig de Sant Andreu (Ullastret), o Illa d'en Reixac (Ullastret) superaban incluso la complejidad de la de Sagunto, y ello sin hacer mención del sistema defensivo de Emporion. Una sucesión de asedios de este tipo hubiera retrasado la marcha, debilitado a los contingentes, y aumentado el número de deserciones entre los poco fiables aliados de algunas tribus ibéricas, pérdidas a las que hubiera debido añadirse el establecimiento de guarniciones para mantener los territorios sometidos, una misión para la que no hubieran bastado los diez mil infantes y mil jinetes del cuerpo de observación del Ebro puesto a las órdenes de Hannon (Tito Livio, XXI, 23). Algunos autores (Healy, 1995a) han indicado asimismo que las negativas de Aníbal a marchar contra Roma después de sus triunfos en las batallas del Lago Trasimeno (217 a.C.) y Cannas (216 a.C.) eran el resultado de su experiencia en el asedio de Sagunto.

Tras su victoria en la Segunda Guerra Púnica, Roma aplasta a principios del siglo II a.C. el último intento de las tribus ibéricas por recuperar su libertad. Marco Porcio Catón demuestra un gran respeto por las fortificaciones de los poblados ibéricos y sopesa las dificultades de tener que desarrollar una campaña de expugnaciones reiteradas cuando dicta la orden de destrucción de sus fortificaciones (Tito Livio, XXXIV, 17), (Frontino, 1, 1, 1,), (Plutarco, Cato Maior, 10, 3), (Apiano, Hispania, XLI), (Polieno, Estratagemas, VIII, 17), (Zonaras, 9, 17), (Aureliano Vict, De vir.illustr, XLVII): «y a cada ciudad envió cartas selladas y a quienes las llevaban les ordenó que las entregasen todos en un sólo día. Y fijó el día, después de haber calculado cuando llegarían a la ciudad más alejada. La carta ordenaba a los magistrados de las ciudades que asolaran las murallas el mismo día en que recibieran la misiva. Si lo retrasaban para el día siguiente les amenazaba con reducirles a la esclavitud. Ellos, vencidos recientemente en una gran batalla, sin saber si tal orden les había sido dada a ellos solos o a todos, temiendo que si a ellos solos, se les considerara despreciables y si a todos, fueran los únicos en retardarla, sin tener oportunidad de comunicarse mutuamente, temerosos de que los soldados que habían venido con las misivas les estuviesen vigilando y considerando como más importante cada cual su propia seguridad, asolaron sus muros a toda prisa, pues una vez que se habían decidido a obedecer, ambicionaban conseguir algún honor por haber actuado con rapidez. De este modo las ciudades de las orillas del Ebro, en un solo día y en virtud de una sola estratagema, ellas por sí mismas derribaron sus muros (...), Tito Livio (XXXIV, 17, 11-12) indica que únicamente Segestica resistió la orden del cónsul, quién tuvo que emplear máquinas de guerra y manteletes para conquistarla. Según Plutarco, este relato tiene su primera versión en la obra de Polibio, de donde es transcrito posteriormente en diversas versiones; Frontino, Zonaras y Apiano, por ejemplo, siguen la narración de Polieno con ligeros matices.

Al igual que en otros casos muy conocidos, como la destrucción de las murallas de Samos por Pericles (Plutarco, Pericles, XXVIII, 1), la orden de desmantelar las fortificaciones de los poblados ibéricos tuvo un marcado fin político puesto que supuso no sólo la pérdida de su capacidad defensiva, sino también el inicio de la descomposición de la estructura social de las tribus, por cuanto las fortificaciones eran el exponente más claro del estatus y del prestigio político-económico de las elites nobiliarias y gentilicias ibéricas por su valor simbólico, cerrando así Marco Porcio Catón el círculo de un desarrollo histórico iniciado en el siglo VI a.C. (Gracia, 1998).

En nuestra opinión, los textos sobre poliorcética de Eneas el Táctico (Poliorcética) y Filón de Bizancio (Poliorcética, Máquinas de guerra) constituyen puntos de partida correctos 
para el análisis de la concepción táctica del uso de las fortificaciones en el ámbito de la cultura Ibérica a falta de otros relatos que expliquen la forma en que los iberos empleaban militarmente las murallas. Aunque se trata de obras escritas en el año 357-355 a.C. la primera (Vela 1991b) y en la segunda mitad del siglo III a.C. la segunda, los principios que reflejan corresponden a ideas vigentes en fechas anteriores puesto que se trata de obras fundamentadas en el relato y análisis de experiencias previas, y no en la teorización abstracta de respuestas a posibles problemas o situaciones futuras. Hemos indicado ya como pudieron difundirse estos principios en el territorio peninsular, y consideramos que los relatos que Polibio y Tito Livio realizan del asedio de Sagunto por Aníbal son suficientemente explícitos sobre el dominio que una ciudad ibera de rango medio tenía respecto a las técnicas de defensa contra ejércitos dotados de máquinas de guerra.

Pese a que se trata de un hecho de fines del siglo III a.C., poner reservas a la veracidad del texto de Polibio partiendo de la base de que el autor pudo incluir en la narración elementos propios de la estrategia de asedio romana supone cuestionar la totalidad del relato de Polibio que es, por otra parte, uno de los más fiables como obra histórica y la base de la mayoría de los textos posteriores, empezando por la obra de Tito Livio. Polibio era, además, hijo de un estratega y participó en dos de las principales campañas del siglo II a.C., las conquistas de Cartago y Numancia, por lo que conocía de primera mano las tácticas militares (entre sus obras perdidas figuran La guerra de Numancia, Sobre la táctica y La vida de Filopemen), experiencia que le permitía diferenciar en su obra las respuestas tácticas que se producen en uno y otro asedio. Si a este hecho añadimos que las últimas modificaciones importantes en el trazado de las fortificaciones se realizan en el siglo III a.C. (p.e. Emporion, Castellet de Banyoles, Turó del Montgròs, La Serreta), incluyen en todos los casos elementos basados en la poliorcética mediterránea, creemos que existe una base sólida para afirmar el conocimiento y la aplicación de los sistemas de ataque y defensa complejos por el mundo ibérico durante la segunda mitad del siglo III a.C.

El período comprendido entre el siglo V a.C. y la primera mitad del siglo III a.C. presenta, obviamente, un mayor número de problemas debido a la ausencia de textos. Es incuestionable, no obstante, que algunos trazados correspondientes al siglo $\mathrm{V}$ a.C. incluyen soluciones técnicas basadas en el desarrollo de la poliorcética posterior a la introducción de máquinas de guerra en el Mediterráneo greco-púnico, y que la existencia de condiciones favorables para la difusión de estos conocimientos en la península Ibérica es asimismo obvia dentro de los circuitos comerciales. Consideramos que el grado de desarrollo de la cultura Ibérica durante el Ibérico Pleno se traduciría también en la incorporación de nuevos conceptos militares.

FranCISCO GRaCia AlONSO

Dpto. Prehistoria, Historia Antigua y Arqueología - Universidad de Barcelona

E-mail:fgracia@trivium.gh.ub.es 


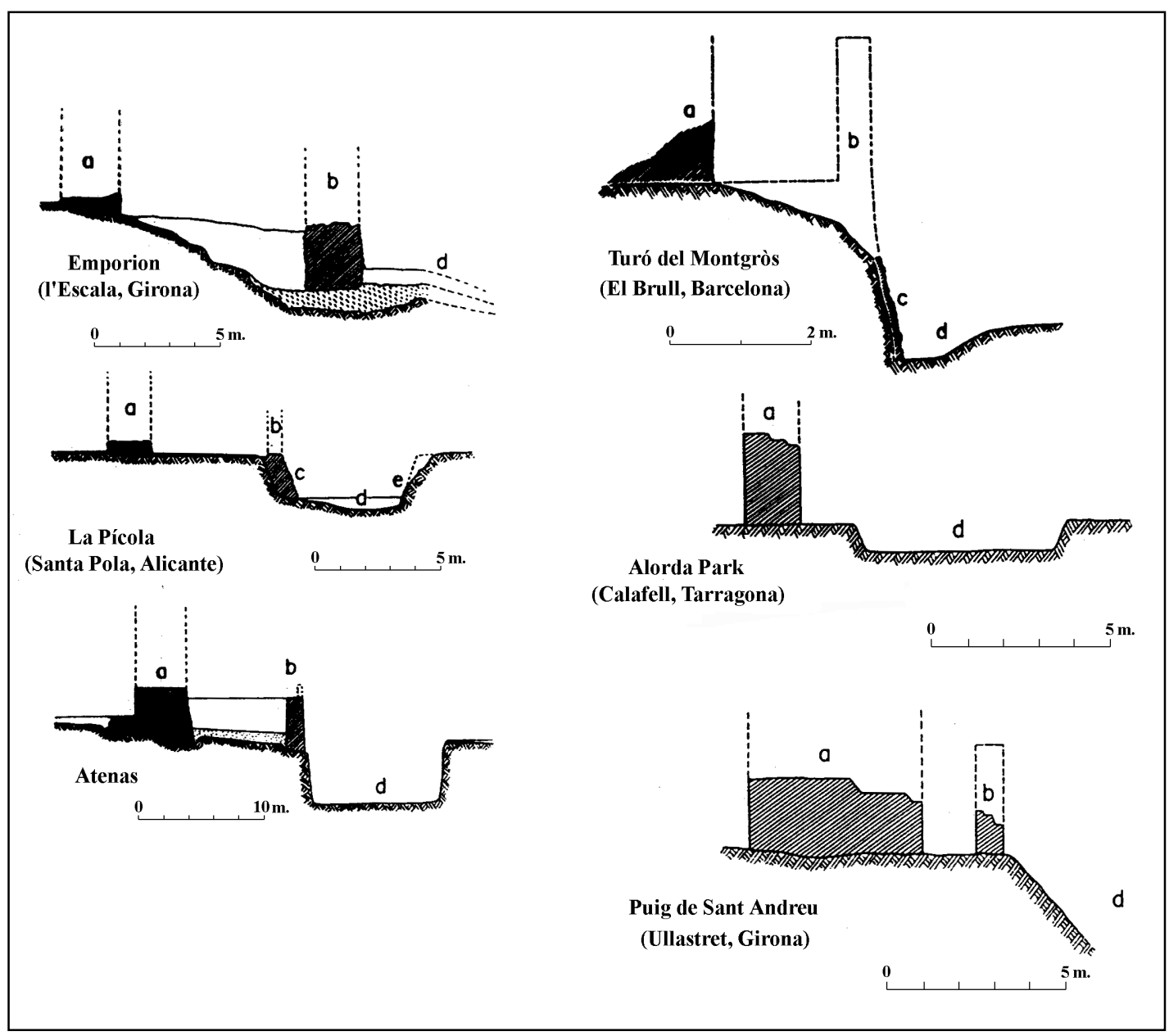

Fig. 1. Aplicación de las teorías poliorcéticas en el trazado de los sistemas defensivos. Empleo en la obras avanzadas de epikampion (b), foso (d) y glacis placado de piedra (c) ante las murallas (a). Esquemas a partir de (Moret el alii, 1994), (Molist, Rovira 1991), (Sanmartí, 1991), (Sanmartí, 1992) y (Oliva, 1968). 


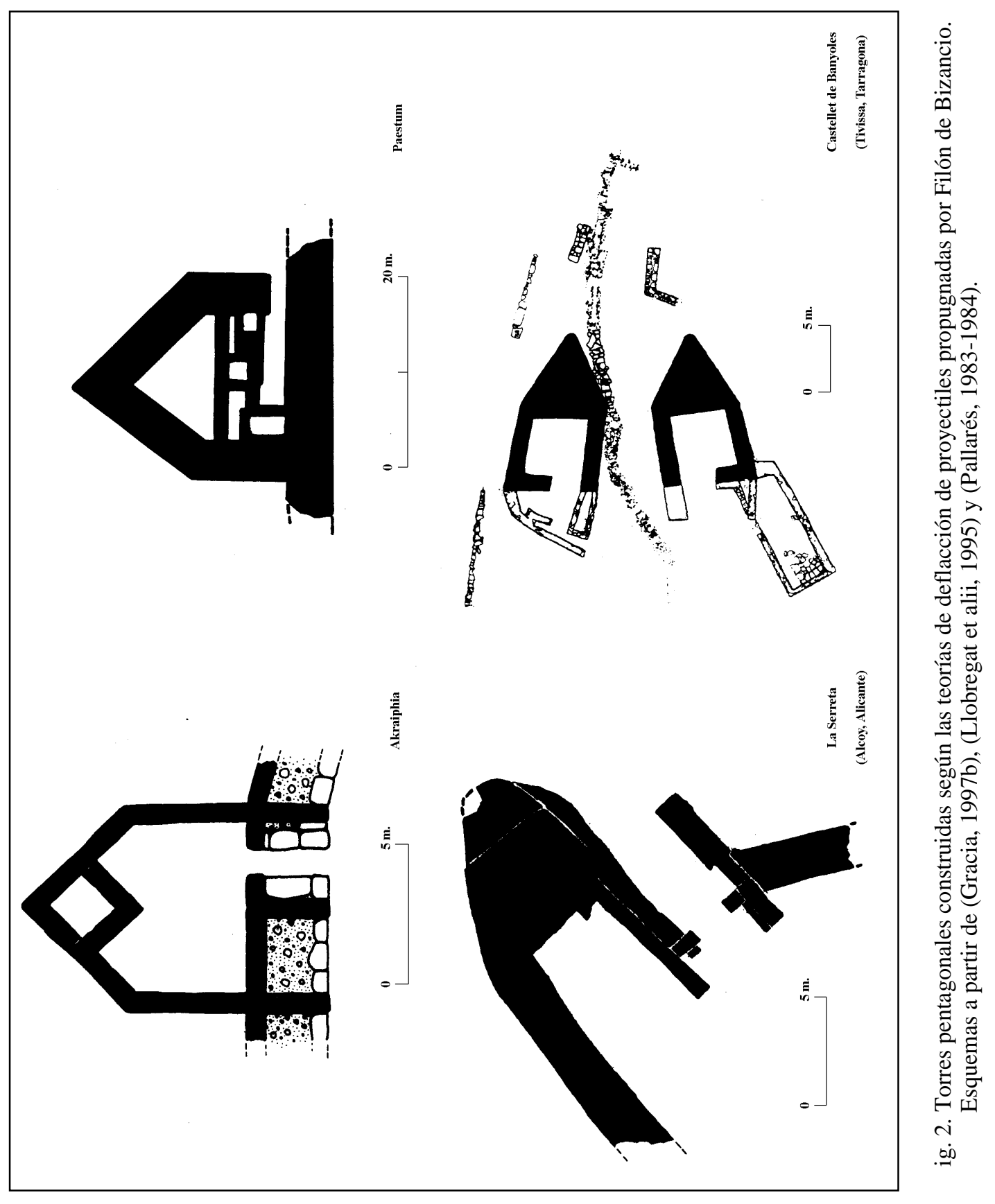



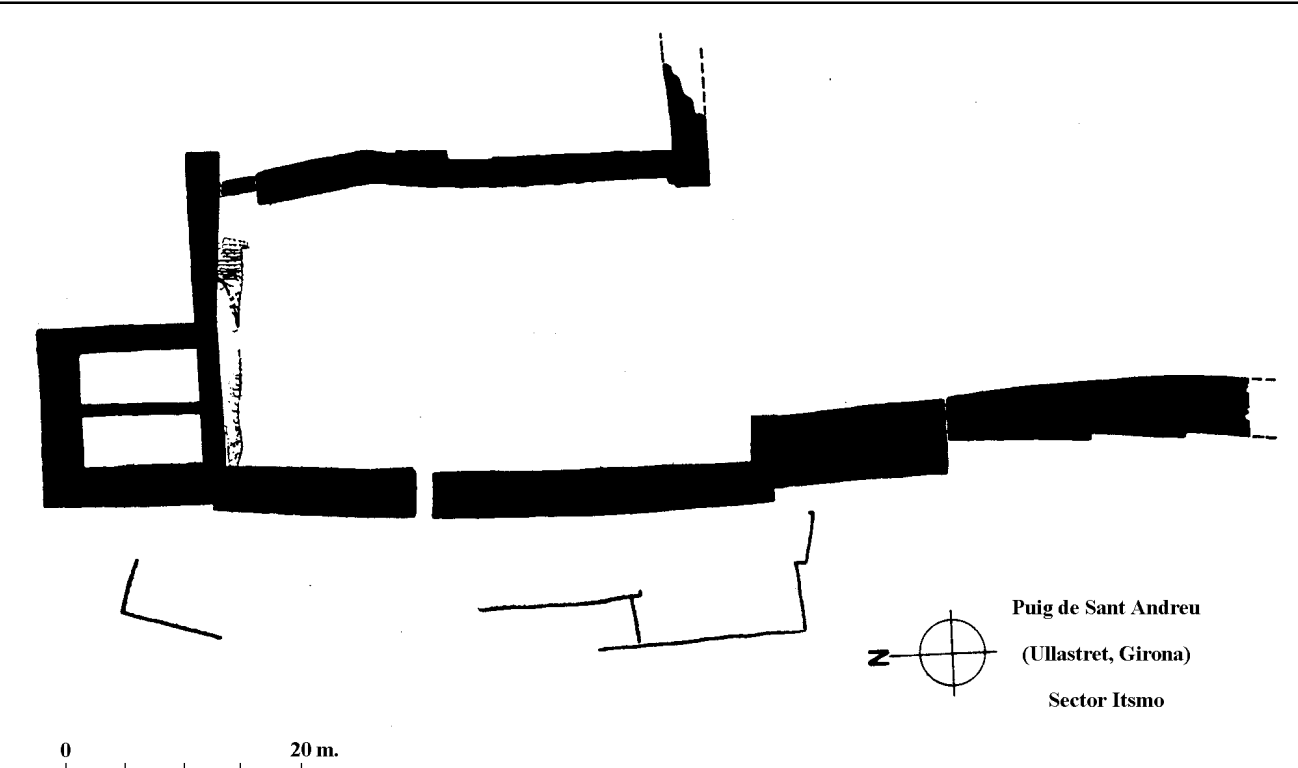
$20 \mathrm{~m}$.

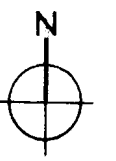

Aegosthenes
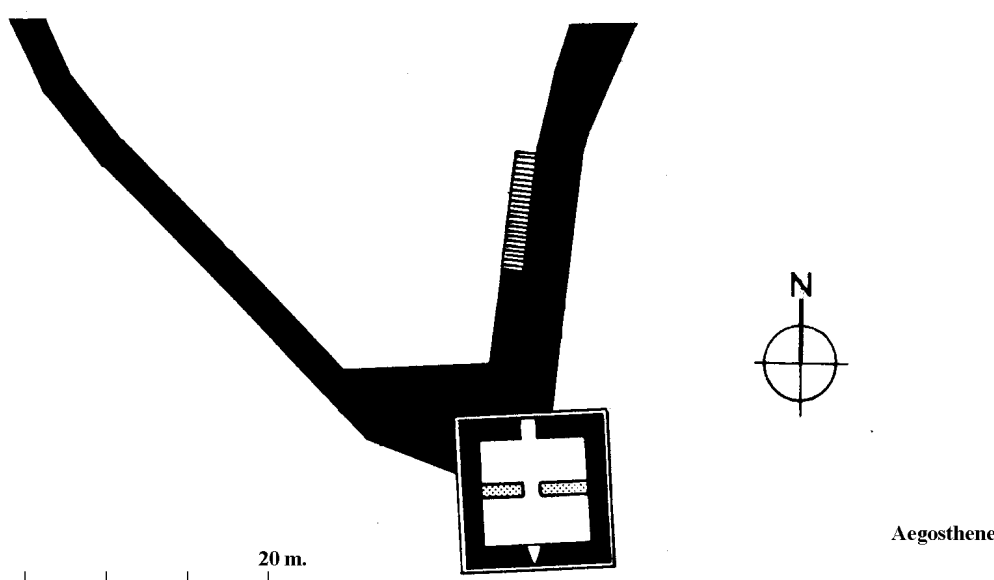

0 $5 \mathrm{~m}$.

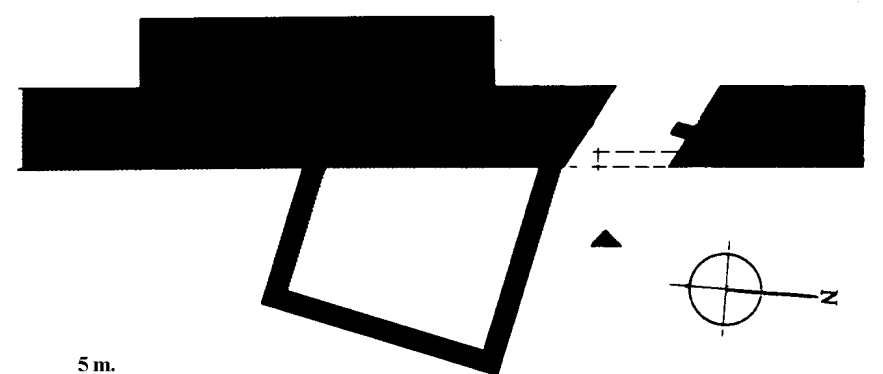

Oinidai

Fig. 3. Combinación del trazado de las murallas en cremallera con torres y poternas en los ángulos del sistema defensivo. Esquemas a partir de (Oliva, 1960), (Adam, 1982). 


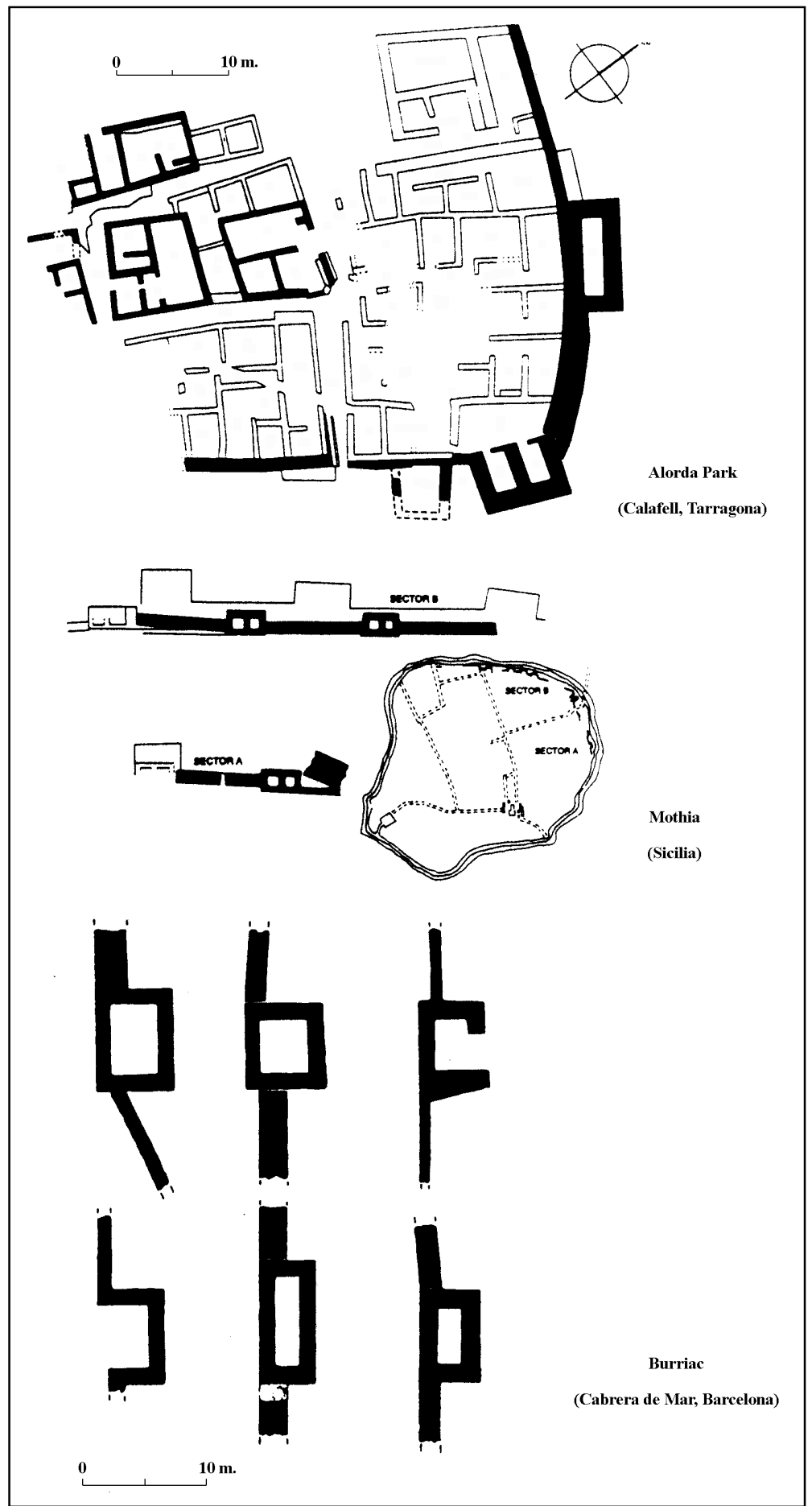

Fig. 4. Empleo de las torres cuadrangulares huecas en los sistemas defensivos ibéricos. El concepto de la fortificación en casamata se empleó profusamente en los sistemas defensivos púnicos del Mediterráneo central. Esquemas a partir de (Sanmartí, 1992). 


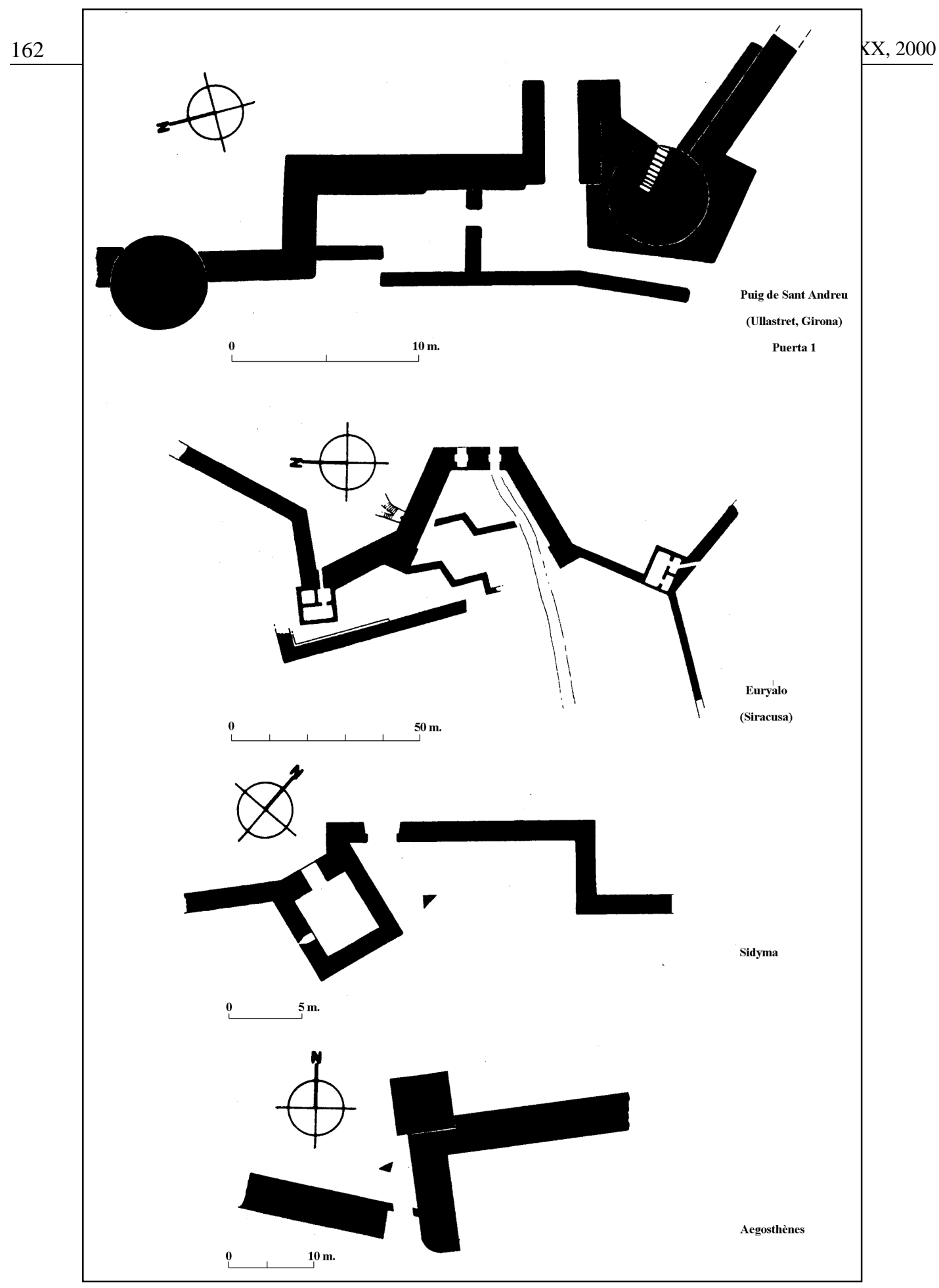

Fig. 5. Construcción de obras avanzadas (proteichisma) ante los accesos a las puertas y modificación del trazado de las torres para adaptarlas a las concepciones poliorcéticas complejas. Esquemas a partir de (Oliva, 1960) y (Adam, 1982). 


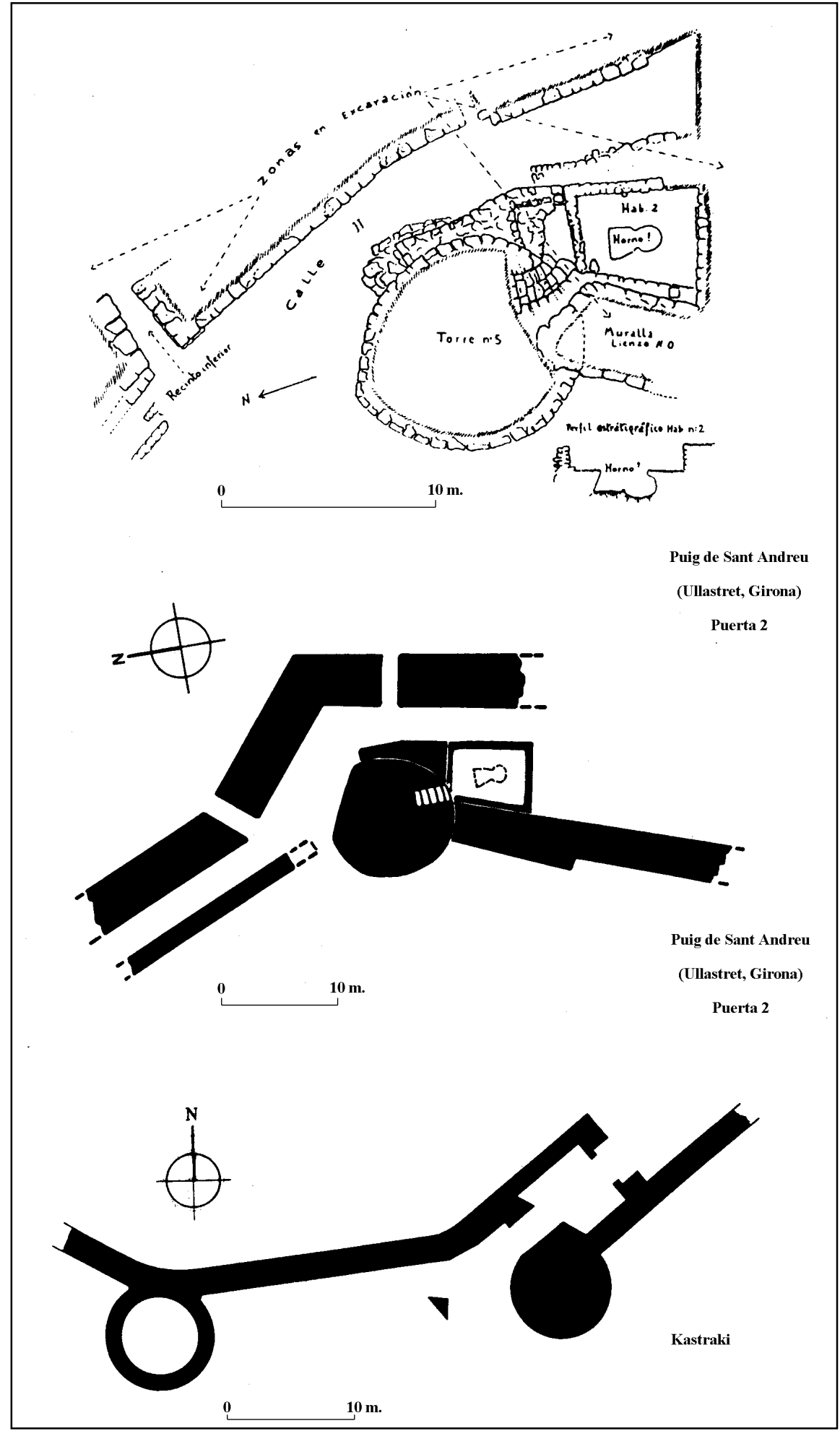

Fig. 6. Combinación del trinomio torre defensiva, poterna y obras avanzadas. Esquemas a partir de (Oliva, 1960) y (Adam, 1982). 


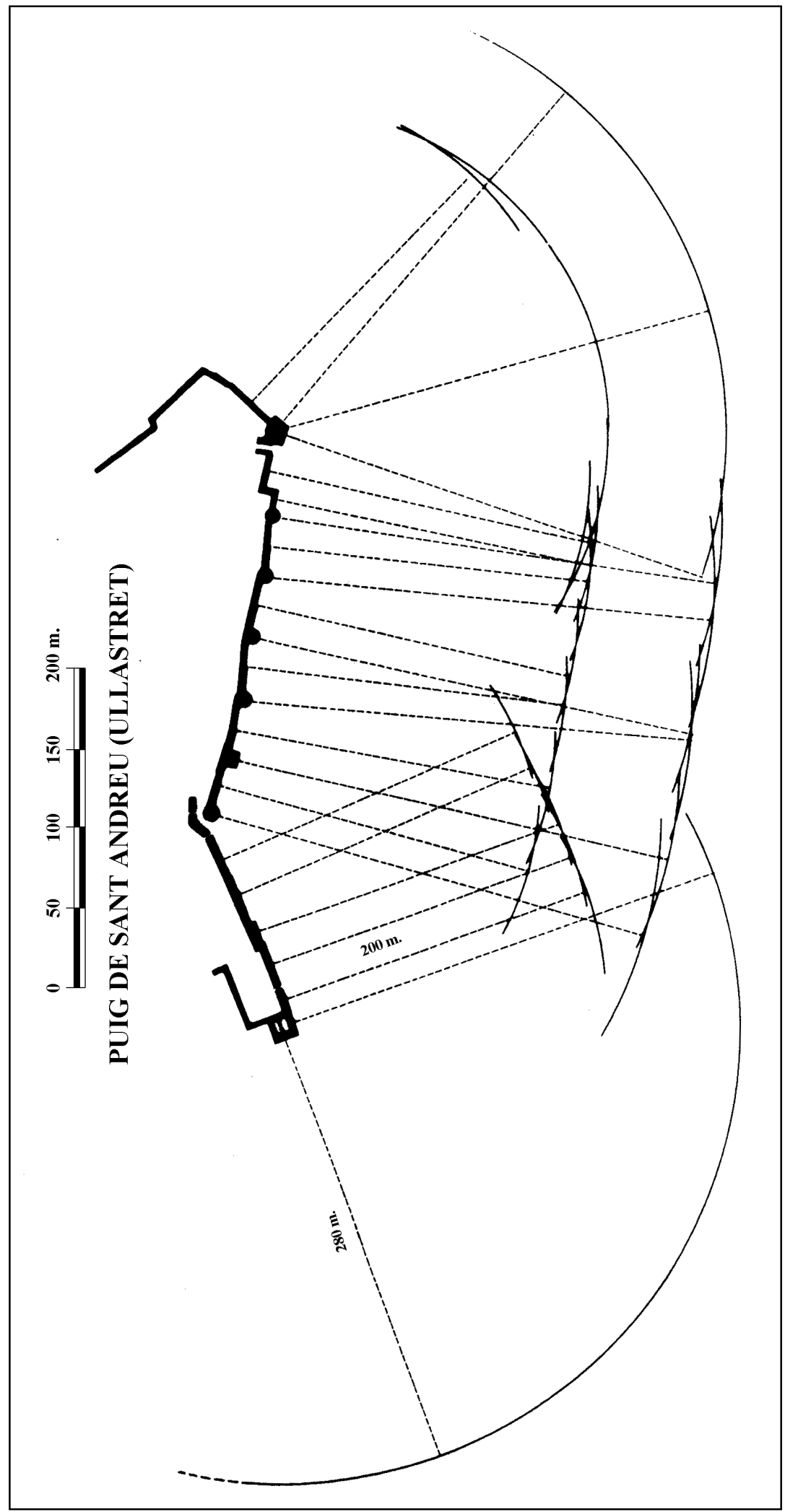

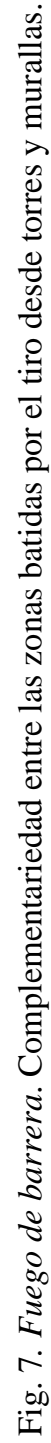




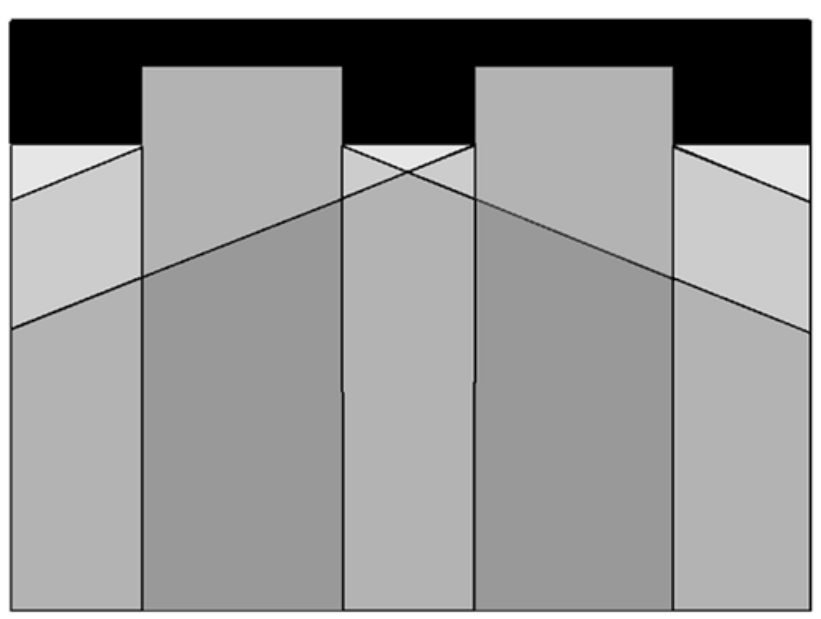

Zona batida desde un tramo de muralla o torre

Zona batida desde dos tramos de muralla o torres

Zona batida desde tres tramos de muralla o torres

Zona batida desde cuatro tramos de muralla o torres
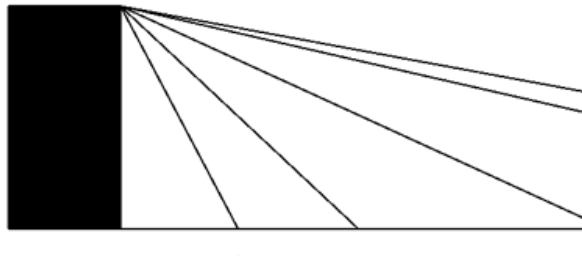

A

B

$\mathbf{C}$
A: Limite efectivo del tiro con arco
B: Límite efectivo del tiro con honda
C: Límite máximo del tiro con honda
D: Límite máximo del tiro con arco
E: Límite máximo del tiro con máquina

Fig. 8. Comparación del terreno batido por los diferentes tipos de armas en un tramo de muralla protegido por torres. 


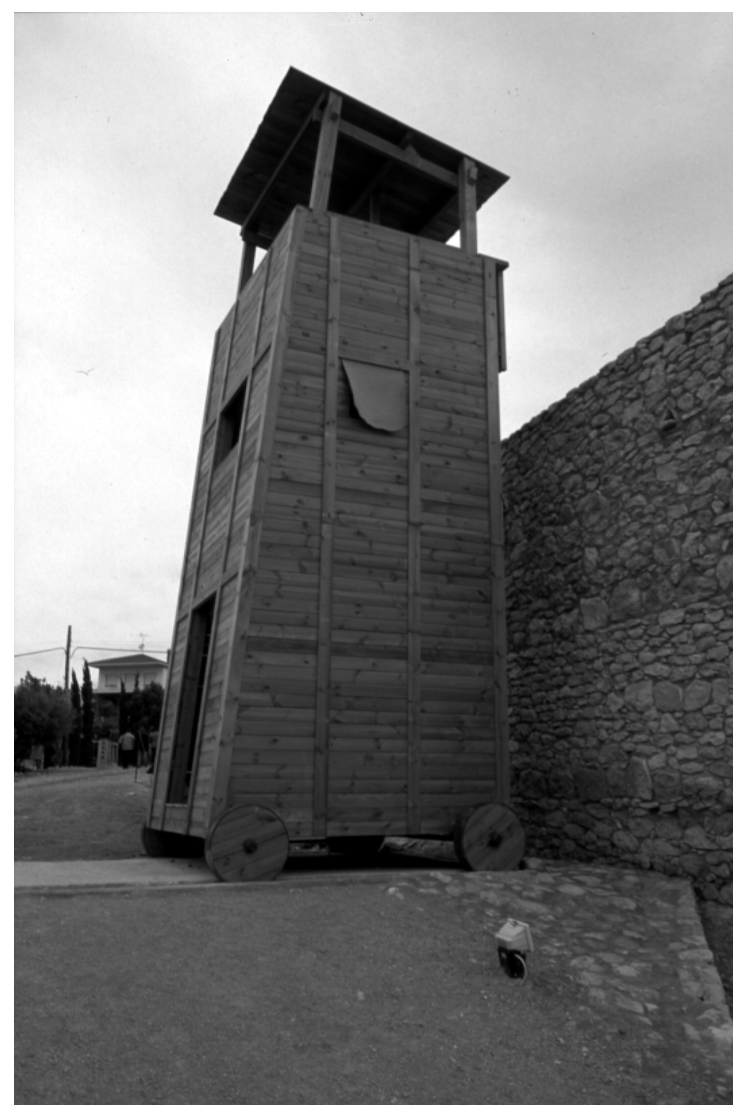

Figs. 9 y 10. Musealización de una torre de asalto en el poblado ibérico de Les Toixoneres (Calafell, Tarragona), realizada por el Taller de Projectes, Patrimoni i Museologia de la Universidad de Barcelona bajo la dirección de Xavier Hernández y Joan Santacana.

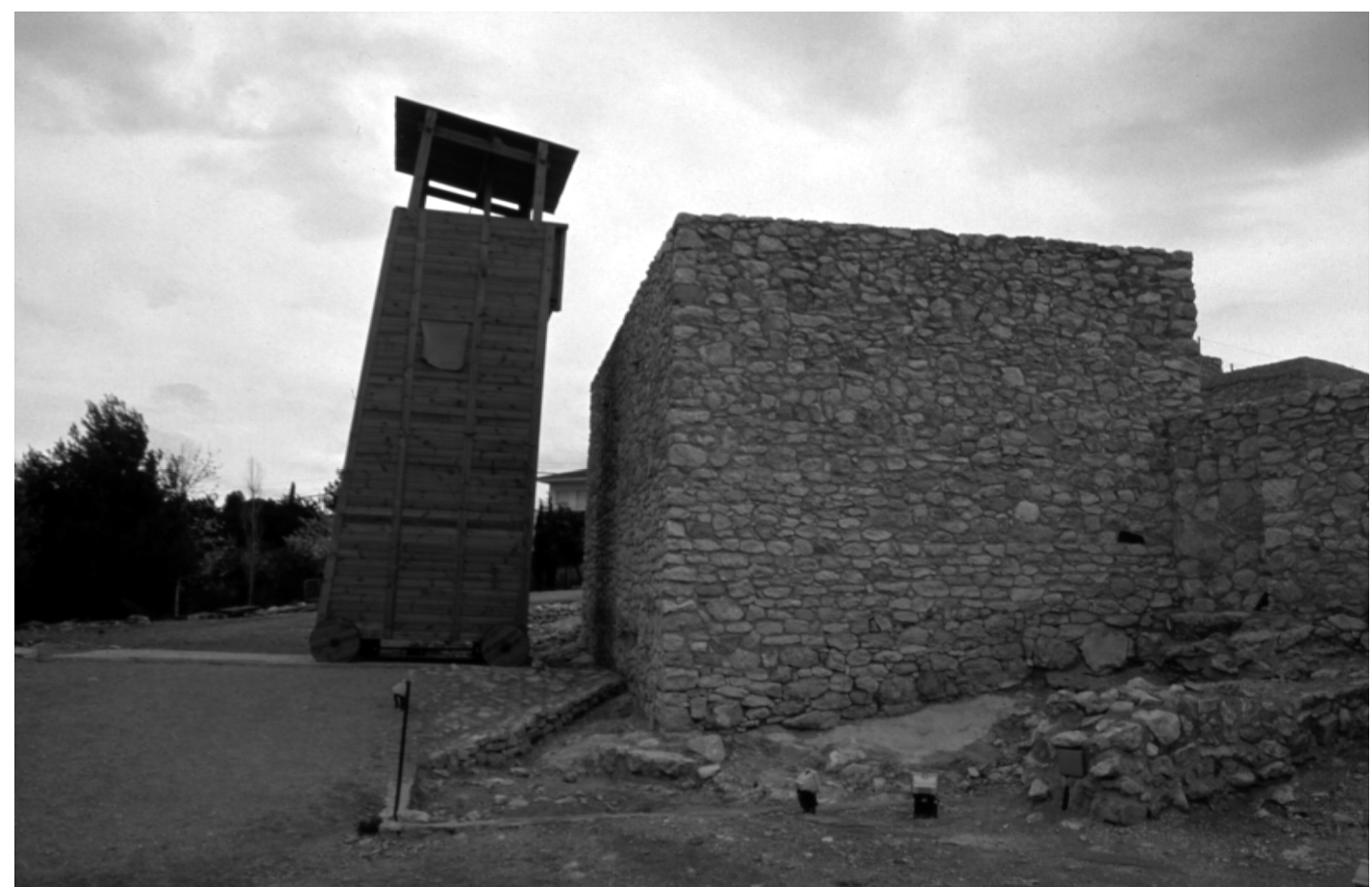




\section{TEXTOS CLÁSICOS}

Cayo Julio César. Cuerra Civil. Ed. Universidad Autónoma de México. México, 1981.

Eneas el Táctico. Poliorcética. Ed. Gredos. Madrid, 1991.

Eneas el Táctico. Poliorcétique. Ed. Les Belles Lettres. París, 1967.

Frontinus. Stratagems and aqueductus. Ed. Loeb Classical Library. Cambridge.

Jenofonte. Expedició dels deu mil. Ed. Bernat Metge. Barcelona, 1977.

Polieno. Estratagemas. Ed. Gredos. Madrid, 1991.

Rochas d'Aiglun, A. de (1872). Traité de fortification, d'attaque et de défense des places par Philon de Byzance. Ed. Société d'Emulation du Doubs. París.

Schulten, A (Ed.) (1935) Fontes Hispaniae Antiquae. Fasc. III. Las Guerras de 237-154 a. de J.C. Barcelona.

Schulten, A (Ed.) (1937) Fontes Hispaniae Antiquae. Fasc IV. Las guerras de 152-72 a. de J.C. Barcelona.

Silio Itálico. Les Guerres Puniques. Ed. Les Belles Lettres. París, 1981.

Tito Livio. Ab Urbe condita/ Historia de Roma desde su fundación. Ed. Gredos. Madrid,1993.

Tucídides. Història de la Guerra del Peloponès. Ed. Bernat Metge. Barcelona, 1958.

Wescher,C. (1867). Poliorcétique des Grecs. Traités théoriques, récits historiques. Ed. Imprimerie Impériale. París.

\section{BIBLIOGRAFÍA}

ADAM, J.P. (1982): L'Architecture militaire grecque. Ed. Picard-CNRS. Paris.

Almagro Gorbea, M. (1983): Pozo Moro, el monumento orientalizante, su contexto sociocultural y sus paralelos en la arquitectura funeraria ibérica. $M M, 24,177-293$.

ANDERSON, J.K. (1970): Military theory \& practice in the age of Xenophon. Ed. University of California Press. Los Angeles.

Azuar, R.; Rouillard, P.; Gailledrat,E.; Moret,P. ;Sala, F.; Badie, A. (1998): El asentamiento orientalizante e ibérico antiguo de «La Rábita», Guardamar del Segura (Alicante). Avance de las excavaciones 1996-1998. TP, 55,2, 111-126.

BARDE, Y. (1996): Histoire de la fortification en France. Ed. PUF. París.

BEndALA, M.; BLANQueZ, J. (1997): El legado bélico mediterráneo. Tartessos y el mundo ibérico. En: AA.VV. La Guerra en la Antigüedad. Una aproximación al origen de los ejércitos en Hispania. Ed. Ministerio de Defensa. Madrid, pp. 135-155.

BennetT, M. (1995): Agincourt 1415. Un triunfo en inferioridad. Ediciones del Prado/Osprey Military. Madrid.

BERGMAN, C.A.; MCEWEn,E.; MiLleR, R. (1988): Experimental archery:projectile velocities and comparison of bow performances. Antiquity, 62, pp. 658-670.

BERROCAL, L. (1994): Arqueología de las fortificaciones griegas (III). Repercusiones entre Púnicos,Iberos y Celtas. Revista de Arqueología, 166, 24-35.

Bonet, H.; MatA, C. (1991): Las fortificaciones ibéricas en la zona central del País Valenciano. Simposi Internacional d'Arqueologia Ibèrica. Fortificacions: la problemàtica de l'Ílèric Ple (segles IV-III aC). Manresa, 11-35.

BRADBURY, J. (1992): The medieval siege. Ed. Boydell Press. Woodbrige.

Clausewitz, K. von (1992): De la Guerra. Ed. Labor. Barcelona.

CoRdente, F. (1992): Poliorcética romana 218 aC-73 dC. Col. Tesis Doctorales, 350. Universidad Complutense, Madrid.

DUCREY, P. (1985): Guerre et guerriers dans la Grèce antique. Ed. Office du Livre. Fribourg. 

París.

FEugÈre, M. (1993): Les armes des romains de la République à l'Antiquité tardive. Ed. Errance.

GARLAN, Y (1974): Recherches de Poliorcetique Grecque. BEFAR, 223. París.

GILlE, B. (1995): La cultura técnica en Grecia. Ed.Juan Granica. Barcelona.

GRACIA, F. (1995): Producción y comercio del cereal en el nordeste de la península Ibérica entre los siglos VI y II aC. Pyrenae, 26, pp. 91-113.

GRACIA, F. (1997a): L'artillerie romaine et les fortifications ibériques dans la conquête du NordEst de la péninsule ibérique (218-195 av.J.C.). Journal of Roman Military Studies, 8, pp. 171-195.

GRACIA, F. (1997b): Poliorcética griega y fortificaciones ibéricas. La Guerra en la Antigüedad. Una aproximación al origen de los ejércitos en Hispania. Ed. Ministerio de Defensa. Madrid, pp. 165-183.

GRACIA, F. (1999): Arquitectura y poder en las estructuras de poblamiento ibéricas. Esfuerzo de trabajo y corveas. Los Iberos. Príncipes de Occidente. Barcelona, 99-114.

Gracia, F.; Munilla, G.; PAllares, R. (1991): Estructuración del poblamiento y sistemas defensivos en el área de la desembocadura del Ebro. Dos casos de estudio: La Moleta del Remei (Alcanar) y el Castellet de Banyoles (Tivissa). Simposi Internacional d'Arqueologia Ibèrica. Fortificacions: la problemàtica de l'Ibèric Ple (segles IV-III aC). Manresa, 67-78.

HANZHANG, T. (1996): El arte de la guerra de Sun Tzu. La interpretación china moderna. Ed. Distal. Buenos Aires.

HARMAND. J. (1976): La guerra antigua. De Sumer a Roma. Ed. Edaf. Madrid.

HEAD, D. (1982): Armies of the Macedonian and Punic Wars 359 BC to 146 BC. Ed. Wargames Research Group Publiction.

Healy, M. (1995a): Cannas 216 aC. Aníbal aplasta al ejército de Roma. Ediciones del Prado/Ospery Military. Madrid.

Healy, M. (1995b): Los antiguos asirios. Ediciones del Prado/Osprey Military. Madrid.

JUNYENT, E.; LAFUENTE, J.; LOPEZ, J. (1994): L'origen de l'arquitectura en pedra i l'urbanisme a la Catalunya occidental. Cota Zero, 10, 73-89.

KYTZLER, B. (1989): Breve diccionario de autores griegos y latinos. Ed. Gredos. Madrid.

Llobregat, E.; Coretll, E.; JuAn,J.; OlcinA, M.; SegurA, J.M. (1995): El sistema defensiu de la porta d'entrada del poblat ibèric de la Serreta.Estudi preliminar. Recerques del Museu d'Alcoi, 4, 135-162.

MALUQUER DE MoteS, J. (1970): Ullastret. Ed. Universidad de Barcelona. Barcelona.

MARSDEN, E.W. (1969): Greek and Roman artillery from 339 BC to the IVth century AD. Ed. Clarendon Press.Oxford.

MARTíneZ, J. (1992): La campaña de Catón en Hispania. Aurea Saecula, 7. Barcelona.

Miller, R.; MCEWEN, E.;BERGMAN, C. (1986): Experimental approaches to ancient Near Eastern archery. World Archaeology, 18, 2, pp. 178-195.

Molinos, M.; Chapa, T.; Ruiz, A.; Pereira, J.; Rísquez, C.; MAdrigal. A.; Esteban,A.; MAYORAL, V.; LlORENTE, M. (1998): El santuario heroico de El Pajarillo. Huelma (Jaén).Ed. Universidad de Jaén. Jaén.

Molist, N.; RoviRA, J. (1991): La fortificació ibèrica del Turó del Montgròs (El Brull,Osona). Simposi Internacional d'Arqueologia Ibèrica. Fortificacions: la problemàtica de l'Ibèric Ple (segles IV-III $a C$ ). Manresa, 244-264.

MONTGOMERY, B.L. (1969): Historia del arte de la guerra. Ed. Aguilar. Barcelona.

Moret, P.; Puigcerver, A.; Roulllard, P.; SÁnchez, M.J.; Sillières, P. (1994): The fortified settlement of La Picola (Santa Pola, Alicante) and the greek influence in South-east Spain. Social complexity and the development of towns in Iberia from the Copper Age to the second century AD. PBA, 86, pp. 109-125. 
MORET, P. (1996): Les fortifications ibériques, de la fin de l'âge du bronze à la conquête romaine. Ed. Casa de Velazquez. Madrid.

MoRET, P. (1998): Rostros de piedra.Sobre la racionalidad del proyecto arquitectónico de las fortificaciones urbanas ibéricas. Los Iberos.Príncipes de Occidente. Barcelona,83-92.

MüLLER, H. (1996): Beobachtungen an befestigungsanlagen in Katalonien. Elemente griechischer befestigungstechnik in Emporion, Ullastret und Tivissa. $M M, 37,86-102$.

Negueruela, I. (1990): Los monumentos escultóricos del Cerrillo Blanco de Porcuna. Ed. Ministerio de Cultura. Madrid.

Oliva, M. (1960): Excavaciones arqueológicas en la ciudad ibérica de Ullastret (Gerona). Undécima campaña de trabajos. Ed. Instituto de Estudios Gerundenses. Gerona.

PAllarÉs, R. (1983-1984): El sistema defensivo frontal del Castellet de Banyoles, Tivissa, Ribera d'Ebre. Pyrenae, 19-20, 113-126.

PELliCER, J.L. (1994): Táctica militar y estrategia en el antiguo Egipcio (Desde los Orígenes hasta finales del Imperio Nuevo). Tesis Doctoral. Universidad de Barcelona.

Prados, L. (1992): Exvotos ibéricos de bronce del Museo Arqueológico Nacional. Ed. Ministerio de Cultura. Madrid.

PRITCHETT, W.K. (1974): The Greek State at War. Ed. University of California Press. Los Angeles.

QUESADA, F. (1989a): La utilización del arco y las flechas en la cultura ibérica. TP, 46, 161-201.

QuesadA, F. (1989b): Armamento, Guerra y Sociedad en la Necrópolis Ibérica de El Cabecico del Tesoro (Murcia,España). BAR International Series, 502. Oxford.

QUESADA, F. (1997a): ¿Jinetes o caballeros?. En torno al empleo del caballo en la Edad del Hierro peninsular. En: AA.VV. La Guerra en la Antigüedad. Una aproximación al origen de los ejércitos en Hispania. Ed. Ministerio de Defensa. Madrid, 185-194.

QUESADA, F. (1997b): Aspectos de la guerra en el Mediterráneo antiguo. En: AA.VV. La Guerra en la Antigüedad. Una aproximación al origen de los ejércitos en Hispania. Ed. Ministerio de Defensa. Madrid, 33-52.

RAMON, J. (1983): Puntas de flechas de bronce fenicio-púnicas halladas en Ibiza:algunos materiales inéditos. Homenaje al Profesor Martín Almagro Basch,II. Madrid., 309-323.

REBOREDA, S. (1988): El arco y las flechas en el Bronce Final y en el Hierro Inicial en Grecia. Gerión,16, 85-99.

SANMARTí, E.; NollA, J.Ma . (1986): Informe preliminar sobre l'excavació d'una torre situada a ponent de la ciutat grega d'Empúries. 6è Col.loqui Internacional d'Arqueologia de Puigcerdà. Puigcerdà, 159-191.

Sanmartí, E.; Castañer, P.; Tremoleda, J. (1988): La secuencia histórico-topográfica de las murallas del sector meridional de Emporion. MM, 29, 191-200.

Sanmartí, E.; CAStañer, P.; Tremoleda, J. (1991): Nuevos datos sobre la historia y la topografía de las murallas de Emporion. $M M, 33,100-112$.

SAnMartí, E.; CASTANYER, P.;SANTOS, M.; Tremoleda, J. (1996): Nota sobre el bastió oriental de la muralla grega d'Emporion. Fonaments,9, 343-250.

SANMARTí, J.; SANTACANA, J. (1991a): Les fortificacions ibèriques de la Catalunya central i costanera. Simposi Internacional d'Arqueologia Ibèrica. Fortificacions: la problemàtica de l'Ibèric Ple (segles IV-III aC). Manresa, 127-144.

SANMARTí, J.; SANTACANA, J. (1991b): El sistema defensiu del poblat ibèric d'Alorda Park (Calafell,Baix Penedès,Tarragona). Simposi Internacional d'Arqueologia Ibèrica. Fortificacions: la problemàtica de l'Ibèric Ple (segles IV-III aC). Manresa, 329-335.

Sanmartí, J.; SAnTACANA, J. (1994): L'urbanisme protohistòric a la costa de Catalunya. Cota Zero,10, 27-37.

SNODGRASS, A.M. (1967): Arms and armour of the greeks. Ed. Cornell University Press. Ithaca. 
Vela, J. (1991a): Eneas el Táctico. Poliorcética. La estrategia Militar Griega en el siglo IV aC. Ed. Ministerio de Defensa. Madrid.

Vela, J. (1991b): Introducción. En: Eneas el Táctico. Poliorcética. Ed. Gredos. Madrid, pp. 9-28. WARRY, J. (1980): Warfare in the Classical World. Ed. Salamander book. Londres.

WINTER, F.E. (1971): Greek Fortifications Phoenix Supplement,IX. Toronto. 